\title{
CLOSEOUT FINAL REPORT
}

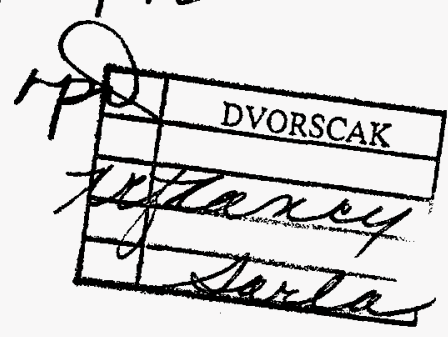

on

\section{A Demonstration Test and Evaluation}

Of the Cannon Low-Nox Digester System $m$ a pacent disengiotnt to the publication or

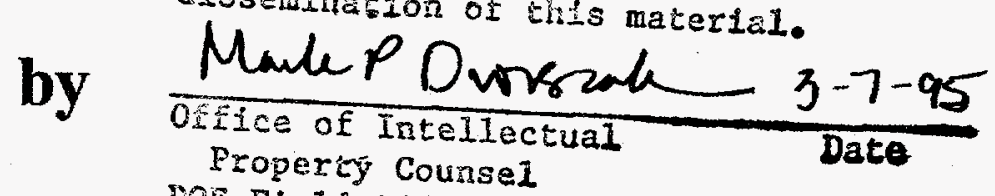

\section{CANNON TECHNOLOGY, INC.}

Subcontractor to

\section{SOUTHERN CALIFORNIA GAS COMPANY}

DOE Cooperative Research Grant No:

DE-FC-92PC92161

to

U.S. Department of Energy

Closeouts

Pittsburgh Energy Technical Center

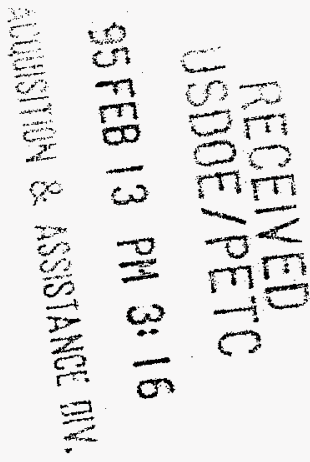

Mail Stop 921-143

P.O. Box 10940

Pittsburgh PA 15236 


\section{DISCLAIMER}

Portions of this document may be illegible in electronic image products. Images are produced from the best available original document. 


\section{TABLE OF CONTENTS}

$1.0 \quad$ Executive Summary

2.0 Program Objectives 2

2.1 System Overview 2

2.2 Chemical Reactions in Gas and Liquid Phases 5

2.2.1 Gas Phase 5

2.2.2 Liquid Phase 5

2.2.3 Reaction Rates 5

3.0 Description of Test Apparatus as Originally Designed 7

3.1 Gas Flow Path 7

3.2 Liquid Flow Paths 7

3.3 The Ozone Supply System 8

3.3.1 The Ozone Generator 8

3.3.2 The Oxygen Supply System 8

3.4 Gas Analysis 9

3.5 Liquid Analysis 9

3.6 The Data Acquisition and Control System 10

3.6.1 Data Acquisition 10

3.6.2 Process Control Logic 10

3.6.2.1 Fan Control Loop 10

3.6.2.2 Scrubber Sump Level Control Loop 10

3.6.2.3 Ozone Injection Control Loop 11

3.6.2.4 Scrubber Spray Pump Control Loop 11

3.6.2.5 Scrubber Sump pH Control Loop 11

3.6.2.6 Holding Tank HT-610 pH Control Loop 11

$\begin{array}{lll}4.0 & \text { Project Objectives } & 12\end{array}$

$\begin{array}{lll}5.0 \quad \text { Statements of Work } & 13\end{array}$

6.0 Progress Report for the Period of the Contract 23

6.1 Tasks Completed During Contract Period 23

6.2 Project Progress Reports 23

6.3 Project Activity Following the End of the Contract

6.3.1 Project Progress From September 29, 1993 to November 30, 1993

6.3.2 Packed Column Optimization Project 24

6.3.3 Slip Stream Tests at Duquesne Light Company's Elrama Power Station $\quad 24$

6.3.4 Extension of SCAQMD Contracts 25 
7.0 Financial Summary

7.1 Overview

7.2 Close-out Financial Forms

7.3 New Financing for Project Continuation

8.0 Progress Report on Activity After September 29, 1993

8.1 LTO System Design Changes

8.1.1 Overview

8.1.2 Detailed Changes in the LTO System 28

8.2 Changes in Test Protocol

8.2.1 Overview

8.2.2 New Test Protocol

8.3 New Project Schedule

\subsection{Conclusions}

10.0 Recommendations

Appendix A: 1. Original P. \& I.D.

2. Latest P. \& I.D.

Appendix B: Project Reports September 30, 1992

to September 29, 1993

Appendix C: Financial Forms and Reports

Appendix D: New Test Protocol for Alta Dena Demonstration

\section{DISCLAIMER}

This report was prepared as an account of work sponsored by an agency of the United States Government. Neither the United States Government nor any agency thereof, nor any of their employees, makes any warranty, express or implied, or assumes any legal liability or responsibility for the accuracy, completeness, or usefulness of any information, apparatus, product, or process disclosed, or represents that its use would not infringe privately owned rights. Reference herein to any specific commercial product, process, or service by trade name, trademark, manufacturer, or otherwise does not necessarily constitute or imply its endorsement, recommendation, or favoring by the United States Government or any agency thereof. The views and opinions of authors expressed herein do not necessarily state or reflect those of the United States Government or any agency thereof. 


\subsection{EXECUTIVE SUMMARY}

Since 1985, Cannon Boiler Works, Inc. has been carrying out research and development efforts to perfect a system for removing nitrogen oxides, NOx, from the exhaust gases of furnaces, gas turbines, chemical reactors, incinerators and boilers.Computer simulations, bench-scale tests and pilot plant testing have proved that the system is capable of removing substantially all of the NOx from natural gas-fired equipment exhaust streams. Furthermore when retrofit to industrial boilers, both capital costs and operating costs are lower than for competing processes, while performance is much better. The Cannon system for removing NOx, originally designated as the Cannon NOx Digester, has recently been renamed the Low Temperature Oxidation (LTO) System for NOx and SOx Reduction. It will be engineered and marketed by Cannon Technology, Inc, a wholly owned subsidiary of Cannon Boiler Works, Inc. Cannon has U. S. patents for the process and for the associated equipment and has patent applications pending in Europe.

Following successful pilot plant tests that were concluded in March of 1991, it was recognized that a full scale demonstration would be necessary before the system could be commercialized. Because California has implemented the strictest NOx emission regulations in the United States, the industry in that state offered the best opportunity for the demonstration. Discussions in California with Cannon's agent in the Los Angeles area led to a proposal to Alta Dena Dairy located in the nearby City of Industry. That company was interested in a NOx reduction system because at that time they were in violation of the Southern California Air Quality Management District's, (SCAQMD's) BACT Guidelines for boilers, in the burner input range of 4 to $33.5 \mathrm{Mbtuh}$ and consequently were threatened with a shut down order. The Dairy's management, however, were unable to find the financial resources to pay for the Cannon LTO system and for the demonstration testing. Southern California Gas Company (SoCalGas), who was Alta Dena Dairy's fuel supplier, was approached for help. They pledged some financial resources and arranged a meeting with personnel at the U.S. DOE's Pittsburgh Energy Technical Center (PETC), late in 1991. An unsolicited proposal was submitted to DOE in the spring of 1992 and that 
was followed by a Cooperative Research Agreement awarded to SoCalGas for the support of the "Cannon Low-NOx Digester System" with the work subcontracted by SoCalGas to Cannon Technology, Inc. The award was announced in the Federal Register of August 14, 1992. Engineering was begun immediately, with the project scheduled for completion at the end of September, 1993.

At the end of the contract period the engineering was completed except for the design of the control system, most of the materials and purchased equipment was requisitioned and some of it was delivered, some of the pre-fabrication was complete and all of the funds budgeted for the project had been expended. Work continued with Cannon internal funding until early in November of 1993 when the project was put on hold due to lack of funds.

A vigorous effort by Cannon to obtain additional funding for completing the project resulted in: 1) a pledge of additional funding from SoCalGas and 2) a liscencing agreement with British Oxygen Corporation (BOC). These additional sources provided sufficient funding to ensure the completion of the demonstration.

During the time that the project was suspended, several engineering changes became necessary because of boiler room alterations at the Alta Dena Dairy. The project has now been restarted, all of the additional engineering and $75 \%$ of the procurement and has been completed. The current project schedule shows tests beginning on May 2, 1995 with a project completion date in 1996.

\subsection{Description of the Cannon LTO Process}

\subsection{System Overview}

Cannon's Low Temperature Oxidation, LTO, process has proved effective for reducing the levels of $\mathrm{NOx}, \mathrm{CO}, \mathrm{CO}_{2}, \mathrm{SO}_{2}$ and particulates from boiler flue gases. A schematic flow 
diagram in Figure 1 on page 4 shows the basic elements that are used to carry out the processes. The principal elements in the system are: 1) a fan, 2) a heat exchanger, 3) an oxidation chamber, 4) a spray chamber acting as a gas/liquid absorber, 5) a demister, 6) An ozone generator (ozonator), 7) a liquid oxygen storage or dry air supply system for the ozonator, ) a chemical storage and metering system for the caustic neutralizer and 10) a data acquisition and control system .

The fan provides a pressure rise in the gas that just overcomes the combined pressure drops in the rest of the process elements. The heat exchanger cools the gas to a more manageable temperature and in so doing becomes a heat source for thermal requirements in the boiler room or the associated plant. Possible uses for the recovered heat are feedwater and make-up water heating and domestic hot water heating. The ozone that is injected into the gas duct is a potent oxidizer. Although most of the pollutants are oxidized to some extent, the reaction rate of ozone and $\mathrm{NO}$ and ozone and $\mathrm{NO}_{2}$ are so rapid in comparison with the other oxidation reactions, that most of the ozone is consumed in converting $\mathrm{NOx}$ to $\mathrm{N}_{2} \mathrm{O}_{5}$. This oxide hydrates in the presence of water vapor in the gas phase to form $\mathrm{HNO}_{3}$ and is then scrubbed out of the gas as it passes through the absorber. The absorber can be constructed as any of a number of possible gas-liquid contacting mass transfer devices. Possible configurations are cross flow, concurrent flow or counter flow spray chambers and random packed or structured packed spray towers. By carefully maintaining the proper $\mathrm{pH}$ of the scrubber liquid in a properly designed absorber, almost complete removal of $\mathrm{NOx}, \mathrm{SOx}$ and $\mathrm{HCl}$ can be assured. At higher temperatures $\mathrm{CO}$ is partially oxidized by ozone to form $\mathrm{CO}_{2}$. 


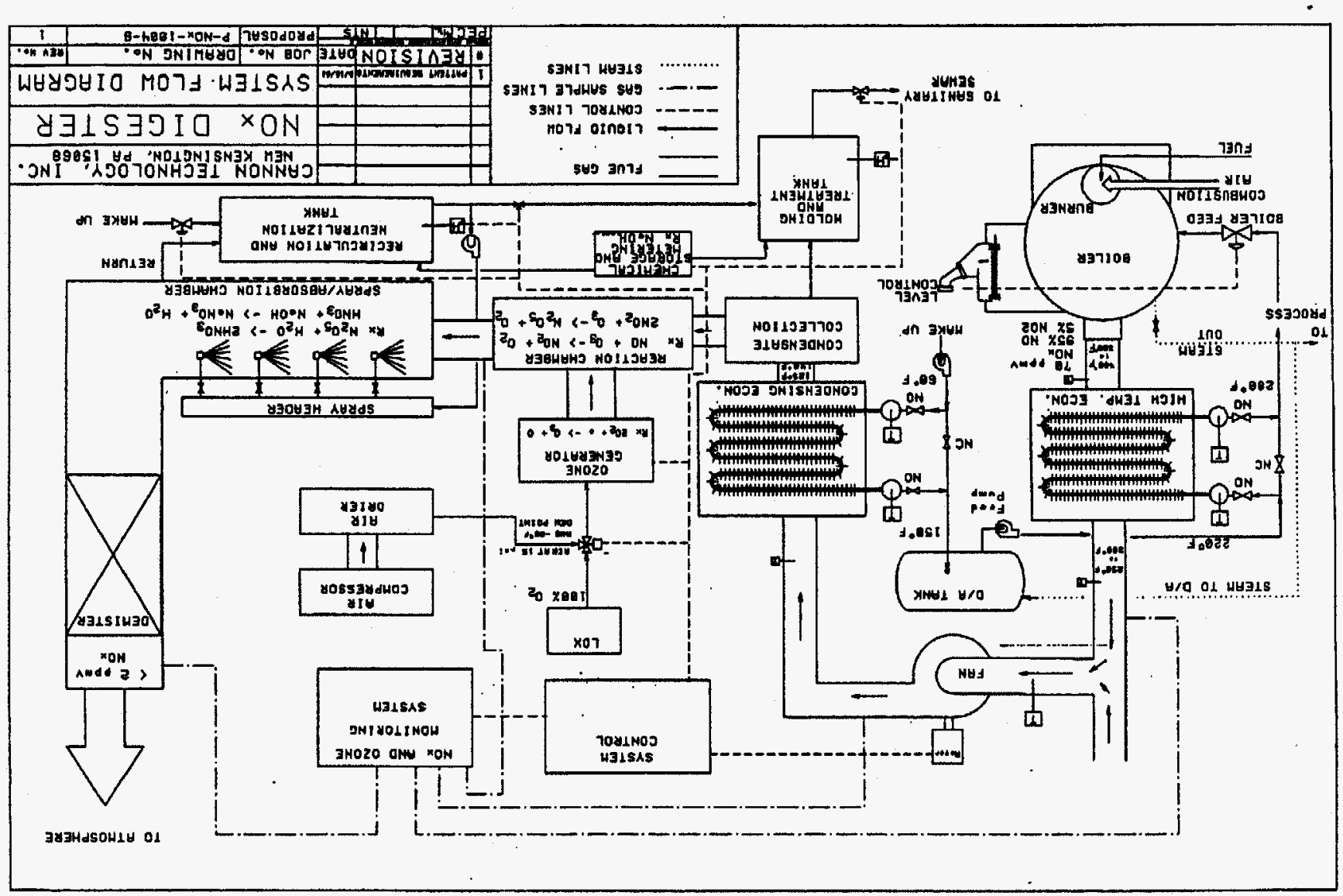

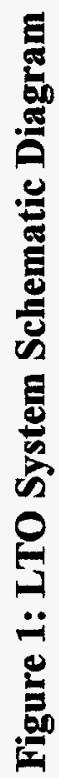




\subsection{Chemical Reactions in Gas and Liquid Phases}

In the reactor, only gas phase reactions occur; while in the scrubber both gas and liquid phase reactions occur simultaneously.

\subsubsection{Gas Phase}

$$
\begin{aligned}
& \mathrm{NO}+\mathrm{O}_{3} \rightarrow \mathrm{NO}_{2}+\mathrm{O}_{2} \\
& 2 \mathrm{NO}_{2}+\mathrm{O}_{3} \rightarrow \mathrm{N}_{2} \mathrm{O}_{5}+\mathrm{O}_{2} \\
& \mathrm{~N}_{2} \mathrm{O}_{5}+\mathrm{H}_{2} \mathrm{O} \rightarrow 2 \mathrm{HNO}_{3} \\
& \mathrm{CO}+\mathrm{O}_{3} \rightarrow \mathrm{CO}_{2}+\mathrm{O}_{2} \\
& \mathrm{C}+\mathrm{O}_{3} \rightarrow \mathrm{CO}+\mathrm{O}_{2} \\
& \mathrm{~N}_{2} \mathrm{O}+\mathrm{O}_{3} \rightarrow 2 \mathrm{NO}+\mathrm{O}_{2}
\end{aligned}
$$

An additional reaction of importance is the dissociation of ozone as given by:

$$
\begin{aligned}
& \mathrm{O}_{3} \rightarrow \mathrm{O}_{2}+\mathrm{O} \\
& \mathrm{O}+\mathrm{O} \rightarrow \mathrm{O}_{2}
\end{aligned}
$$

\subsubsection{Liquid Phase}

$$
\begin{aligned}
& \mathrm{Na}_{2} \\
& \mathrm{CO}_{2}+2 \mathrm{NaOH} \rightarrow \mathrm{NO}_{2} \mathrm{CO}_{3}+\mathrm{H}_{2} \mathrm{O} \\
& 2 \mathrm{HNO}_{3}+\mathrm{Na}_{2} \mathrm{CO}_{3} \rightarrow 2 \mathrm{NaNO}_{3}+\mathrm{CO}_{2}+\mathrm{H}_{2} \mathrm{O} \\
& \mathrm{HNO}_{3}+\mathrm{NaOH} \rightarrow \mathrm{NaNO}_{3}+\mathrm{H}_{2} \mathrm{O}
\end{aligned}
$$

\subsubsection{Reaction Rates}

The rates of production of the higher oxides by ozone reactions can be simplified to the following expression involving the products of the concentrations of the reacting species: 


$$
\mathrm{dC}_{3} / \mathrm{dt}=\mathrm{C}_{1} \times \mathrm{C}_{2} \times \mathrm{k}_{0}
$$

where $\mathrm{C}_{1}$ is the concentration of the reacting species, $\mathrm{C}_{2}$ is the concentration of ozone, $\mathrm{C}_{3}$ is the concentration of the higher oxide and $k_{o}$ is the rate constant for the particular oxidation reaction. $\mathrm{k}_{\mathrm{o}}$ is a function of temperature only, as is indicated below:

$$
\mathrm{k}_{\mathrm{o}}=\mathrm{A} \times \operatorname{EXP}(\mathrm{E} / \mathrm{RT})
$$

where $\mathrm{A}$, a characteristic of the reaction, is a weak function of temperature, $\mathrm{E}$ is a constant for the reaction and $\mathrm{R}$ is the universal gas constant. Substituting the expression for $k_{0}$ from equation (12) into equation (11):

$$
\mathrm{dC}_{3} / \mathrm{dt}=\mathrm{C}_{1} \times \mathrm{C}_{2} \times \mathrm{A} \times \operatorname{EXP}(\mathrm{E} / \mathrm{RT})
$$




\subsection{DESCRIPTION OF TEST APPARATUS AS ORIGINALLY DESIGNED}

In the following subsections of Section 2.0, all equipment identification symbols and location designations refer to those shown on the Piping and Instrumentation Drawing ( $P$. \& I.D.) numbered D7390-1, Rev. H, dated June 26, 1993, which is found in Appendix A.

\subsection{The Gas Flow Path}

A portion of the flue gas from the existing boiler is returned back to the burner air inlet through the flue gas recirculation (FGR) duct. This return flow constitutes approximately $15 \%$ of the normal boiler flue gas exit flow and is effective in reducing the the thermal NOx generated in the boiler to a level below $40 \mathrm{ppmv}$. The remaining $85 \%$ of the exhaust gases, at a temperature of approximately $410^{\circ} \mathrm{F}$, pass through a high temperature economizer HX-50 and leave at a temperature of approximately $267^{\circ} \mathrm{F}$. The energy given up by the exhaust gases heat the boiler feed water, which is returned from the existing deaerator to the economizer. The gases are then diverted from the stack by the damper CD 23 and are drawn through a 24 inch tee and enter the fan F-10 through the flow measuring orifice FE 11 . The orifice pressure drop is sensed by the differential pressure cell DPT-11.2 The fan is driven by an automatically controlled variable speed motor which supplies a pressure rise of magnitude to just overcome the pressure drop through the LTO system. Thus the fan is able to maintain normal boiler exhaust conditions. The gases then pass through a condensing economizer HX-30 which drops the gas temperature from approximately $257^{\circ} \mathrm{F}$ to $126^{\circ} \mathrm{F}$ and condenses approximately $4 \%$ by weight of the water vapor. The waste heat recovered by the economizer is used to heat the make-up water to the boiler which is then delivered to the deaerator. This is a successful strategy since the boiler requires $100 \%$ make-up water.

The gas leaving the economizer is injected with ozone before entering the static mixer SM-210, where it is well mixed with the ozone before entering the reactor vessel ND-200. The reactor is an empty cylinder designed with the dimensions which will give the gas a residence time of three (3) or four (4) seconds. This is the necessary time period which insures the complete oxidation of $\mathrm{NO}$ and $\mathrm{NO}_{2}$ to $\mathrm{N}_{2} \mathrm{O}_{5}$. The $\mathrm{N}_{2} \mathrm{O}_{5}$ is partially hydrated to $\mathrm{HNO}_{3}$ by the water vapor in the gas and the spray from the fog nozzles at the exit from the reactor. The gas then enters the vertical spray tower TW-400, where the remaining $\mathrm{N}_{2} \mathrm{O}_{5}$ and $\mathrm{HNO}_{3}$ vapor are absorbed by the circulating spray water. The cleansed gas then passes through the demister DM-430 before it is released to the atmosphere.

\subsection{The Liquid Flow Paths}

The scrubber (absorber) tower TW-400 consists of two vertical stages in tandem. The scrubber liquid ( either water, an alkaline solution, or an acid solution) is circulated in parallel through the two stages by pump P-410 and the flow is controlled by the valves 
MC-402 and MC-409. The tower's sump/holding tank shown on the drawing as HT-420 is an integral part of the tower structure. The spray fluid is metered by the turbine type flow meters FT-401 and FT-408. The pH of the fluid, which is measured by $\mathrm{pH}$ meters PHT-422 and PHT-413, is controlled by adding sodium hydroxide (NaOH) to the absorbent at the circulating pump inlet.

The sodium hydroxide is stored in the 55 gallon drums CTK-650 and CTK-670 and is delivered to the scrubber by the chemical pump MP-640. The condensate from the condensing economizer is delivered by gravity to the holding tank HT-45 and the drainage from the reactor vessel to the holding tank HT-450. The spent absorbent from the tower sump, along with the contents of the holding tanks HT-45 and HT-450, is delivered to the metering tank HT-620 and then to the holding tank HT-610. The measuring tank, HT620 , is automatically dumped to the holding tank HT-610 when the solenoid valve DCV631 is activated by the level control LAHH-621, when the tank is full. The number of times that the solenoid valve is activated is stored in a counter in the data acquisition and control system as a measure of the liquid discharged to the sewer. The $\mathrm{pH}$ meter PHT611 controls the chemical pump MP-660 in order to adjust the $\mathrm{pH}$ within the limits mandated by the public sewer authority. The solenoid valve DCV-615 discharges the liquid in the holding tank HT-610 whenever signaled by the high level controller LAH617.

\subsection{The Ozone Supply System}

Ozone for the oxidation of NOx is generated on site, using a corona discharge ozonator with a capacity of $50 \mathrm{lb}$. per day of ozone, as a $6 \%$ by weight solution of ozone in oxygen.. The ozonator is powered by a medium high frequency, high voltage, alternating current power supply. The oxygen is supplied by a pressure swing type, adsorbent-bed plant which separates oxygen from the ambient air.

\subsubsection{The Ozone Generator}

Oxygen is supplied to the ozonator through the metering orifice FT-527 and the flow is controlled by valve V-528. The cooling water for the generator comes from the chilled water system introduced through valve V-534. The cooling water flow is measured by the flow meter FT-545 as the water exits the generator. The ozone/oxygen mixture is injected into the boiler exhaust gas through valve V-534 at the inlet to the static mixer. The rate of ozone supply to the exhaust gas is regulated either by controlling the oxygen flow rate to the ozone generator or by controlling the corona discharge current, which changes the concentration of ozone in the oxygen.. The ozone concentration, in per-cent by weight, is measured with meter 03-539.

\subsubsection{The Oxygen Supply System}

Ambient air is supplied to the oxygen supply system by the screw type compressor C-500, operating at 90 psig. Pulsations are damped out in the receiver tank T-510. The pressure 
swing adsorption system consists of four (4) tanks, O2T-512, 522,520 and 523, containing molecular seives that concentrate the oxygen from the air. The oxygen generator delivers $900 \mathrm{scfh}$ of oxygen at a purity of $90 \%$.

\subsection{Gas Analysis}

Gas sampling ports for NOx measurements are provided at these locations: 1) the condensing economizer exit (NOx-43), 2) the entrance to the static mixer (NOx-38) and 3 ) the exit from the scrubber tower ( $\mathrm{NO}-433$ and $\mathrm{NO}_{2}-439$ ). A chemiluminescent type gas monitor is used to measure the concentrations of $\mathrm{NO}, \mathrm{NO}_{2}$ and $\mathrm{NOx}$. The instrument that is used is a Monitor Laboratory Model 8840, which is now being produced by LearSiegler Corporation. The instrument is direct reading, but also transmits the data to the data acquisition and control system (D.A. \& C.) as a 4-20 ma signal.

The per-cent ozone meter, which measures the concentration, by weight, of the ozone in the ozone/oxygen mixture injected into the boiler exhaust gas, is an UV absorption type meter with the model designation $\mathrm{HC}$ made by PCI, Inc. It provides a panel indication as well as a 4-20 ma signal to the D.A. \& C. System. The ozone concentration entering and exiting the ozone destructor is measured by an IN-USA Model IN-2000 UV absorption meter. This instruments also provides a panel indication as well as a 4-20 ma signal to the D.A. \& C. System.

Electrochemical cells will be used for measuring $\mathrm{NO}, \mathrm{NO}_{2}$ and ozone concentrations for control purposes. They will all be EIT Corporation Series 4500 Sensor Sticks with transmitters to send 4-20 ma signals to the D.A. \& C. System.

\subsection{Liquid Analysis}

The $\mathrm{pH}$ of the spray liquid and that of the contents of the chemical holding tanks are measured with Great Lakes, Model 6028PO transmitting $\mathrm{pH}$ meters, whose signals are transmitted to the D.A. \& C. System for processing and storage.

Some external chemical analyses will be made on the scrubber liquids to determine the exact species of the solutes and their concentrations. These analyses will be done by a commercial laboratory using ion chromatography.

For several tests, liquid samples will be drawn from the scrubber sump, at measured intervals, during a period over which the flow rates of all liquids entering and leaving the sump will be carefully measured and recorded. Chemical tests of those samples will determine the concentrations of nitrates/nitrites of each and the rate of build-up of those species in the scrubber sump. This rate can be compared with the difference of the rate of NOx flow into and out of the scrubber.This comparison will serve as a mass balance on Nitrogen for the LTO system and will constitute a quality control check on the test data and/or a physical confirmation of the validity of the process design. 


\subsection{The Data Acquisition and Control System}

\subsubsection{Data Acquisition}

The data aquisition and control system is based upon a personal computer with an Intell 486D CPU running at $33 \mathrm{MHz}$ clock speed and with a hard disc drive mass storage facility and floppy disc I/O drives. Data from all instrument and control sensor transmitters will be scanned at ten second intervals and temporarily stored. The data needed for control will be utilized immediately and then discarded. The archival data will be processed to give averages over an arbitrarily selected time period and the derived data set stored over a twenty four (24) hour period. Each days data will then be dumped to a floppy disc for eventual analysis and final storage.

The final demonstration tests of the Cannon LTO System will be witnessed by SCAQMD personnel and the stack emission tests will be made by an independent contractor, using a portable laboratory approved by SCAQMD.

\subsubsection{Process Control Logic}

\subsubsection{Fan Control Loop}

Fan FE-10 is required to move the entire boiler exhaust gas flow through the LTO system and the system will have an overall pressure drop that is a strong function of the flow. In order to ensure that the fan operating point is not dictating an excess backpressure on the boiler, it will be necessary to backfeed the static pressure at the boiler exit. The control philosophy for this loop is duct pressure feedback. The fan is directly driven by a variable speed motor controlled by a variable frequency drive. This motor drive has a built in controller for closed loop fan control applications which will respond to a signal from a PLC which is proportional to the static pressure deviation of the boiler exit from the outlet pressure setpoint.

\subsubsection{Scrubber Sump Level Control Loop}

The level of scrubber liquid in the sump is controlled by a modulating makeup valve MV424 and a solenoid drain valve DCV-428. The makeup valve opens/closes in response to the level transmitter LT -423 . Level switch LAH-427 will give a high level alarm (software alarm) when the sump level is 6 inches below the inlet gas duct level and will also send an "open" signal to drain valve DCV-428 in case the level transmitter fails to open the valve. Level switch LAL-426 will give a low level alarm (local and software) and send an "open" signal to the make up valve MV-424 in case the level transmitter fails to open the valve. An open overflow line (not shown on P. \& I.D.) at the top of sump HT420 will maintain the maximum level in the sump. 


\subsubsection{Ozone Injection Control Loop}

The demand signal for ozone injection is derived from the flue gas flow as measured by the flow measuring orifice FE-11 and the NOx concentration at port NOx-43. The ozone injection rate is based on the process setpoint (PLC input) parameter of the molar ratio of ozone to NOx $(\mathrm{O} 3 / \mathrm{NOx})$. This is a feedforward control signal that generates the setpoint for the ozone generator output controller. The ozone generator has an internal PLC for simultaneous regulation of $\mathrm{O}_{2}$ input and $\% \mathrm{O}_{3}$ concentration.

The ozone injection control loop is configured to control the scrubber stack NOx levels to below $2.0 \mathrm{ppmv}$. The actual $\mathrm{NOx}$ and $\mathrm{O}_{3}$ concentrations are fed back to adjust (bias) the ozone injection output setpoint. In situ analyzers ( the EIT Sensor Sticks) will be used for feedback control because of their fast response time (10 to 15 seconds). The Senser Sticks require a minimum oxygen concentration of $5 \%$ by volume; thus precluding the use of the Sensor Sticks for feedforward control.

The ozone injection control algorithm uses the flue gas mass flow measurement (pressure and temperature compensated) from DPT-11.2 and the feedforward NOx concentration in ppmv from port NOx-43. and the process setpoint $03 / \mathrm{NOx}$ ratio to calculate the required ozone mass flow at any particular boiler load. This setpoint is then biased up or down from the feedback signals from port NO2-439 to achieve minimum NOx levels.

\subsubsection{Scrubber Spray Pump Control Loop}

The total flow of scrubber liquid to the nozzles of the scrubber sections is controlled by the position of control valves MC-402 and MC-409. The flows are measured by the turbine flowmeters FT-401 and FT-408 (Great Lakes Model F1A11B2/MHF 16H2). The required flows are used as operator input setpoints for the corresponding control valves.

\subsubsection{Scrubber Sump pH Control Loop}

The $\mathrm{pH}$ of the scrubber liquid is controlled by the injection of $\mathrm{NaOH}$ from either of the two chemical tanks (drums). There are two pH sensors in the loop (PHT-413 and PHT422), one of them redundant, and they provide the feedback signal to control the caustic $(\mathrm{NaOH})$ flow. The $\mathrm{pH}$ setpoint is an operator input signal.

\subsubsection{Holding Tank HT-610 pH Control Loop}

The $\mathrm{pH}$ of the spent liquor to be discharged to the sewer is controlled by the injection of $\mathrm{NaOH}$ from either of the two chemical tanks (drums). The $\mathrm{pH}$ sensor PHT-611 provides the feedback signal to control the caustic $(\mathrm{NaOH})$ flow. The $\mathrm{pH}$ setpoint is an operator input signal. 


\subsection{PROJECT OBJECTIVES}

The principal objectives of the demonstration of the Cannon LTO system at Alta Dena Dairy are:

1. to show that the Cannon LTO system is capable of removing all NOx pollutants from the exhaust gas stream of a natural gas fired steam boiler as was indicated by bench tests, pilot plant tests and process modelling and simulation.

2. to provide the physical data needed for more accurately designing The LTO system for both similar sized and scaled up and scaled down systems. The most important parameters to be fixed are the required residence times for the exhaust gas in the reactor vessel and the scrubber and the required $\mathrm{O}_{3} / \mathrm{NOx}$ ratio for complete $\mathrm{NOx}$ removal. When those three parameters are known, the sizes of the reactor vessel and the scrubber tower can be minimized and the ozone generator sized correctly.

3. for providing the test data required to optimize the scrubber operation. This includes the nozzle type, the scrubber liquor flow rate and the chemistry of the scrubber liquor.

4. to provide the physical data needed for accurately predicting the economics of the Cannon LTO system retrofit to a natural gas fired steam boiler. Realistic estimates of both the capital and operating costs are critically necessary in determining the market potential and the market success of the system.

5. to determine the ability of the control system to react to sudden changes in boiler operation so that NOx emissions are minimized at all times, including startup and shutdown conditions. The data from non-steady state tests will be used to refine the control system design.

6. to minimize the NOx emissions from the Alta Dena Dairy boiler(s) and thus to provide the company with NOx Pollution offsets and/or credits. 


\subsection{Statements of Work}

A copy of the Statement of Work from the U.S. DOE Contract DE-FC22-92PC92161 is found on pages 14 through 17. A copy of the Statement of Work from the SCAQMD Contract S-C93111 is found on pages18 through 22.

Generally speaking, the two above referenced contracts required that Cannon Technology design, procure and/or construct, install and carry out a series of demonstration tests on a Cannon LTO System retrofitted to a process steam boiler at the Alta Dena Dairy in the City of Industry, California. The results of these tests were then to be reported back to the supporting agencies. The detailed work statements, found on the following pages of this section, elaborate on those tasks. 


\section{SIATEMENT OF YORK}

DE-FC22-92PC92161

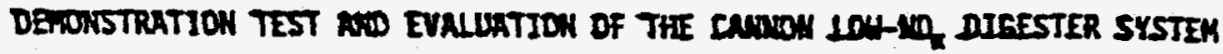

\subsection{Backaround}

The Pittsburgh Energy Technology Center has selected for award an unsolicited proposal from the Southern Californta Gas Company to install a new technology at the Alta-Dena Dairies in Los Angeles. Local air quality regulations andate a reduction of $\mathrm{NO}_{\mathrm{x}}$ emissions at the Dafries' natural gas-fired boiler from the current $85 \mathrm{ppm}$ to less than $10 \mathrm{ppm}$. Retrofit equipment will be designed and fabricated by the Cannon Bofler Works of Hew Kensington, Pennsylvania.

The Cannon Low NO, Digester system involves cooling the flue gases in a combustion air preheater, and the subsequent injection of ozone from an ozone generator. In passing through a reaction vesse?, the insoluble oxides of nitrogen in the flue gases are converted to nitrogen pentoxide, which is removed by means of a water spray. The resulting acidic solution is neutralized continuously with a base to form a weak salt solution that can be discharged to the sanitary sewer. Tests conducted previously by Cannon indicate that the remanat $N_{x}$ effluent aight be as low as 2 ppm.

\subsection{Scope of Nork}

The Cannon Low- $\mathrm{O}_{\alpha}$ Digester treats the flue gases from a boiler to reduce the level of $\mathrm{NO}_{\mathrm{k}}$ to a low, residual level. Although the system removes $\mathrm{SO}_{2}$ also, the boiler selected for this project is fired on natural gas, which has an insignificant content of sulfur. Consequently, only $\mathrm{NO}_{\mathrm{x}}$ reduction is relevant to this project. 
The project involves retrofitting to an existing boller the equipent comprising the Cannon technology: primarily heat exchangers, an ozone generator, a spray chamber, a reaction chamber, denister, a neutralization systea and associated instrunentation. After a shake-down period, the participant will conduct three phases of testing. each of about one month duration; in addition, there will be approximately four months of monitored, routine operation of the boiler. The entire project, including design, fabrication and installation of equipment, will occupy about one year.

\subsection{Insk 1: Retrofit \& Prearation}

The participant shall design, fabricate and install at the AltaDena Dafries all equipient comprising the Lem-10, Digester System, as well as the sccessories and instrowentation needed to perform the proposed demonstrition and testing. Following the installation work, instruments shall be calibrated and shake-down procedures performed in preparation for test runs.

\subsection{Task 2: Phase I Testing}

\subsubsection{Sub-tusk2.1: Bast-line-Test}

In order to establish a record of base-line conditions before application of the Cannon technology, the boiler shall be operated with flue gases passing through the digester equipient but by-passing the heat exchangers. The ozone generator and spray equipment shall not be activated during this period.

\subsubsection{Sub-task 2.2: Recupertitor Performance Test}

Following the base-line test, the participant shall activate the-recuperators. Ozone shall not be eaployed 
during this test, the purpose being to deteraine the performance of the heat exchangers and the resulting improvement in boiler efficiency.

\subsubsection{Sub-tisk 2.3: Repulut may Gromoliance Test}

Subsequently, the full system shall be activated to allow a $\mathrm{NO}_{\mathrm{x}}$ enission of $40 \mathrm{ppmr}$ for the reuainder of the Phase I period; this $\mathrm{NO}_{x}$ level corresponds to the maximum concentration allowed by the South coast Air Quality Kanagement District.

\subsubsection{Sub-tnsk 2.4: Interim Technical Report}

At the completion of testing in Phase I, a report shall be prepared evaluating the perforance of the Low- $\mathrm{MO}_{\mathrm{x}}$ oigester System. Topics of interest include the stability of the systen on automatic controls, response to load changes, and the economics of operating at regulatory compliance conditions. The report shall describe the condition of the ozone generator and the consumption of oxygen and power.

\subsection{Insk 3: Phase 11 Iesting}

\subsubsection{Sub-task 3.1: Mininum_m, Iest}

The participant shall operate the boller to enit the lowest level of $\mathrm{NO}_{\alpha}$ possible at the stack. Parametric testing shall be used to assess the effects of varying the water flow rate and droplet size in the spray chamber. The tests in this phase shall encompass both a circulating alkaline solution and external neutralizing of a water spray; several neutralizing agents shall be tested. 


\subsubsection{Sub-task 3.2: Determintion of ootimum Conditions}

following the parametric testing, the participant shall select the prefarred conflguration and operating condltions for the low en. Digester Syste and shall deteraine the aperating cost for the recomanded $\mathrm{MO}_{\mathrm{x}}$ reduetion.

\subsection{Insk 4: Routine Operation}

The boller shall be operated on a routine basis at the optinum condittons selected by the participant. During this period the data from the system shall be wonftored to check specifically for unexpected excursions or any degradation in performance.

\subsection{Inst 5: Phase-1II Testing}

Following the period of routine' operation, the participant shall review the configuration and operating conditions selected previousiy, and implement any changes that are indicated.

With final operating conditions established, the participant shall operate the boller for a period of demonstration. Invitations to witness the operation shall be issued to the sponsors of the project. 


\title{
FUELD DEMONSTRATION OF THE CANNON NOX DIGESTER
}

\author{
WORK STATEMENT FOR \\ CANNON BOIER WORKS, INC.
}

Errissions control technologies are perceived by end users to be capital intensive equipment that result in reduced boller efficiency and increased operating and maintenance costs. This perception is particularly true of post-combustion, exhaust gas after-treatments such as Selective Catalytic Reduction (SCR), CONTRACTOR has developed an exhaust gas treatment technology that appears to offer a viable, cost-effective alternative for reduction of NOx emissions from-boilers. The objective of this project is to demonstrate the Cannon NOx Digester on a 17 million Btu per hour boiler located at Alta-Deta Dairies in the City of Industry.

The Cannon NOx Digester system is a combination of state-of-the-art heat transfer technology and aqueous absorber. A finned-tube, high temperature recuperator cools the exhaust gases from the boiler from about $400 \mathrm{~F}$ to about $300 \mathrm{~F}$ using boiler feedwater. The high temperature recuperator is followed by a condensing recuperator that reduces the exhaust gas temperature to about $130 \mathrm{~F}$. The innovation of the condensing recuperator both conditions the exhaust gases for downstream NOx reduction treatment and recovers heat energy typically lost up boiler stacks.

The ccoled exhaust gases are mijed with ozone in a reaction charober that oxidizes all the nitric oxide (NO) to nitrogen dioxide $\left(\mathrm{HO}_{2}\right)$ and Ligher vider oxides of nitrogen. The higher order oxides of nitrogen, which are very soluble in water, are then removed in a downstream spray chamber/absorber. Pilot plant performance of a prototype system achieved NOx reductions of over 95 percent and NOx emission levels to about $2.0 \mathrm{ppm}$. This emissions reduction performance is comparable to the performance of SCR.

CONTRACTOR will conduct this demonstration through the following TASKS:

\section{TASK 1-DESIGN AND PROCUREMENTT}

CONTRACTOR will design a NOx Digester system for installation on a 17 million Btu per hour boiler located at Alta-Dena Dairies in the City of Industry. The NOx Digester design will include:

1.1. Development of process flow diagrams that specifies all process flowrates and mass balances for the Alta-Dena site installation of the Cannon NOx Digester system.

1.2. Development of general srrangement drawings that lay out NOx Digester system equipment locations at the site.

1.3. System detail drawing that specify system details for the site installation. 
1.4. Development of construction drawings that specify structural components, foundation requirements, interfaces with existing site equipment, and other details required for construction and field installation of the NOx Digester system at the site.

\section{TASK 2-FABRICATION}

CONTRACTOR will fabricate and manufacture all components and equipment required for the NOx Digester System to be installed at the site. The equipment will be fabricated to meet the specifications and design requirements developed in Task 1. The equipment will inclide the following:

2.1. Heat exchangers - High temperature economizer and condensing conomizer to maximize energy efficiency.

2.2. Fan and fan housing - to maintain adequate draft through both the boller and the NOx Digester system.

2.3. Ozone generator - to provide oxidant to convert NO to water soluble, higher orders of oxides of nitrogen.

2.4. Reaction chamber - to provide for adequate mixing and residence time for the ozone to completely react with the $N O$ in the exhaust gas.

2.5. Spray chamber - to inject water that will absorb the higher oxides of nitrogen and to collect resulting aqueous solution.

2.6. Chemical feed system - to treat and maintain aqueous solution resulting from spray/absorption chamber.

2.7. Structural steel - required to support equipment.

2.8. Ductwork and steel - required to re-route boiler exhaust gases to NOx Digester system.

2.9. Fabricated piping - required for NOx Digester system process flows.

2.10. Electrical panel - for process equipment operation and system control.

2.11. Instrument and control package - instrumentation to monitor and control NOx Digester system.

\section{TASK 3 - FIELD INSTALLATION}

CONTRACTOR will construct and install all required NOx Digester equipment at the site. This on-site construction will include:

3.1. Site preparation - Preparation of the site to accept the NOx Digester system, including moving and/or relocating existing equipment, removing insulation on piping and dueting to prepare for interfacing NOx Digester equipment with existing site equpment, and other activities to facilitate installation of NOx Digester equipment. 
3.2. Foundations - Preparation and installation of foundations to support NOx Digester equipment, including heat exchangers, fans, air compressor, ozone generntor, reaction chamber, spray/absortion chamber, demister, and/or other system equipment requiring foundations.

3.3. Structural steel - Installation of structural steel supports for the NOx Digester equipment fabricated in Task 2.

3.4 Equipment installation - Installation of the NOx Digester system, described in Task 2 , at the site.

3.5 Piping installation - Installation of piping reguired NOx Digester system, including the economizers, water spray system for spray/absorption chamber, chemical treatment system, compressed air, and other systems.

3.6 Electrical installation - Installation of all electrical components and wiring for the operation and control bf the NOx Digester system.

3.7 Instrumentation installation - Installation of all instrumentation required to operate, monitor, and control the NOx Digester system.

\section{TASK 4-SYSTEM START-UP}

CONTRACTOR will start-up the NOx Digester system to verify that all components are operating properly and to design specifications established in Task 1. This will include the heat exchangers (economizers), fan, spray systems in the spray/absorption chamber, control systems, ozone generator and monitor, and air preparation system. Start-up will include debugging of the system to adjust and/or repair equipment as necessary to achieve proper operation of all components.

\section{TASK5-BASEIINE TESTING}

CONTRACTOR will conduct a 30-day, shake-down test of the NOx Digester system at the site. This will inchude the following:

5.1. CONTRACTOR will document uncontrolled boiler performance during the first week of testing. This will be accomplished by ducting the boiler exhaust gas to bypass the economizers and to pass through the NOx Digester, but without operating the ozone generator or water spray system. The objective of this testing is to provide an accurate basis with which to compare and evaluate the NOx Digester system when it is fully operational. The following test data will be recorded for the entire test period asing a digital computerbased control and data acquisition system.

- Temperatures of the exhaust gas stream at five locations between the boiler outlet to the stack.

- Exhaust gas vohume flow rate

- NOx concentrations at the entrance and exit of the reaction chamber.

- Ozone concentrations at the entrance and exit of the reaction

chamber.

- Ozone concentration at the stack exit. 
- Water flow rate to the spray chamber.

- Water pressure at the spray nozzles.

- $\quad$ pH of spray solution.

- $\quad$ pH of solution in holding tank.

- $\quad \mathrm{pH}$ of recuperator condensate.

- Temperature of recuperators' inlet and outlet gas streams.

- Pressures at five locations along the ducts.

- Electrical energy used by tho system.

- Water quantity used by the system.

- Time and date clock to correlate performance parameters with time.

- Elapsed time meter.

- Stean flow rate.

- Feed water low rate.

- Makeup water flow rate.

- For selected test periods, Oxygen ( $\mathrm{O}_{2}$ ), Carbon Monoxide (CO), and NOx will be measured at the stack exit.

5.2. CONTRACTOR will activate and evaluate system recuperators during the second week of baseline testing. The objective of this test period is to determine the heat exchanger performance and-boiler efficiency improvement that results from the recuperators. All test data listed in subtask 5.1 will be recorded during this second week of testing.

5.3. CONTRACTOR will adjust the NOx Digester system to achieve NOx emission levels of $40 \mathrm{ppm}$ (corrected to $3 \% \mathrm{O}_{2}$ ) and operate the system for the final two weeks of this baseline evaluation period. The objective of this testing is to evaluate system performance at conditions that comply with District Rule 1146. All test data listed in subtask 5.1 will be recorded during this test period. The results from this test period will be evaluated and an economic analysis of the system operating costs to maintain compliance will be summarized by the CONTRACTOR in an Interim Technical Report.

\section{TASK 6-CANNONNOXDIGESTER SYSTEMOPTIMIZATION}

CONTRACTOR will optimize the NOx Digester system to operate at the minimum achievable NOx emissions, with the goal being less than $2.0 \mathrm{ppm}$ (corrected to $3 \%$ (2). The expected duration of these tests is about three weeks. All test data listed in subtask 5.1 will be recorded during this test period. The optimization tests will include:

6.1 Spray/Absorption chamber experiments - CONTRACTOR will determine optimum water spray rates and droplet size. Water flow rate will be optimized by varying the number of nozzles installed in the spray system. Spray droplet size will be optimized by changing spray nozzle orifice sizes and nozales pressuro.

6.2 Neutralizing methodology tests - CONTRACTOR will evaluate several neutralizing agents that can be used as to either neutralize a water absorbent spray in a separate process outside the spray/absorption chamber or to create a basic solution to be used as the absorbent in the spray/absorption chamber. Based on the results of these tests, CONTRACTOR will select the optimum, cost-effective neutralization scheme to be used for long term operation of the NOx Digester system. 


\section{TASK 7 - LONG TERM TESTING AND MONITORING}

CONTRACTOR will establish optimum, minimum NOx operating conditions to be used for the long term operation of the NOx Digester system based on the results from Task 6. The NOx Digester will be operated by the site and monitored for a period of about nine months to demonstrate long term performance of the system. All test data listed in subtask 5.1 will be recorded during this test period.

At the end of this long term operating period, CONIRACTOR will conduct a 30 day test period of the system to make tinal adjustments to the system as indicated by the long term data and operators' experience: CONTRACTOR will coordinate testing from an independent, third party testing organization, witnessed by District personnel to verify final system performance.

\section{TASK 8 - REPORTING}

CONTRACTOR shall prepare and submit the following reports documenting this project:

8.1. Monthly progress reports (2 copies) due by the 10 th day of the month following the reporting period. The progress reports should include the following information:

a. Reference to District contract number and title of project.

b. Reporting time period (month, year).

c. Description of work completed during the reporting period, including design; fabrication; installation; testing completed and any available test results; problems encountered and bow those problems were resolved; progress of subcontracted efforts; and other relevant activities.

d. Discussion of work planned for the next reporting period.

e. Discussion of project status with respect to time schedule and steps being taken to resolve any delays.

f. Discussion of cost status with respect to budget status and work completed to date, costs to date, explanation of any overnun, and steps being taken to bring costs back into line.

8.2. Interim Technical Report (2 copies) submitted no later than one month following completion of Task 5 . The Interim Technical Report should provide the following information:

a. Test planned for the baseline evaluation of the NOx Digester system.

b. Discussion of test actually completed witb an explanation of any deviations from the test plan.

c. Presentation of all available test results and measurements including,

as applicable, graphical data presentations.

d. Discussion of test results, including observations during testing, problems encountered and explanation of any data inconsistencies.

e. Economic analysis of the NOx Digester based on the operating costs

required to meet District Rule 1146 emission limits.

f. Appendix of all data collected during the tests. 


\subsection{PROGRESS REPORT FOR THE PERIOD OF THE CONTRACT}

\subsection{Tasks Completed During Contract Period}

During the contract period from September 30, 1992 to September 29, 1993, the following tasks were completed:

1. Heat and mass balances for the Cannon LTO System were created.

2. The engineering was completed except for the data acquisition and control system

3. The P.\& I.D. and the system layout drawings were made.

4. Materials for construction were ordered and delivered.

5. $75 \%$ of the in-house manufacture of system components was accomplished.

6. $100 \%$ of procured items were selected.

7. $80 \%$ of component procurement was accomplished.

8. Installation of a flue gas recirculation system on the Alta Dena boiler was made by a sub-contractor.

Although the completion of all of the above tasks was necessary before the system could be installed at the Alta Dena Dairy, none of those were specifically spelled out in the PETC Work Statement. The manufacture and procurement were approximately $80 \%$ completed, but installation of the Cannon LTO System had not begun when the project was halted.

The tasks that were completed or were at least $75 \%$ complete comprise tasks 1 and 2 in the SCAQMD Work Statement

\subsection{Project Progress Reports}

Copies of the Project Progress Reports submitted to SoCalGas and SCAQMD covering the period from September 30, 1992 to July 31, 1993 are found in Appendix B.

\subsection{Project Activity Following the End of the Contract Period}

\subsubsection{Project Progress From September 29, 1993 to November 30, 1993}

Work was continued, at no reduction in pace, until the end of November, 1993. At that time all of the money that had been committed for the project had been expended and Cannon had carried the project, using its own resources, as far as the company's financial condition would permit. By that time it had become apparent that projected changes in the Alta Dena Dairy boiler room would require significant alteration of the LTO system layout. The project was then suspended in November of 1993 until new financial support could be arranged. 


\subsubsection{Packed Column Optimization Project.}

In December of 1993, Cannon Technology and Carnegie Mellon University, with support from the Ben Franklin Technology Center of Western Pennsylvania began a project to optimize the design of packed columns used for NOx removal from flue gases. The results of the project was an optimization package that, when applied to one specific example of NOx control for a nitric acid plant, found a design with a $25 \%$ cost improvement. This was reported in a paper by Suchak and Diwekar at the AIChE Spring Meeting on April 20, 1994 in Atlanta, Georgia.

\subsubsection{Slip Stream Tests at Duquesne Light Company's Elrama Power Station.}

Cannon Technology, Inc. proposed to Duquesne Light Company on January 19, 1993 that a slip-stream demonstration of the Cannon LTO System be carried out at the Elrama Power Plant.

On March 16, 1993, Cannon received from Duquesne Light Company a letter of intent to proceed with the preliminary work for the proposed demonstration and agreed to enter into negotiations to procure the said demonstration of the Cannon LTO System in a test series using a slip stream from the 501 Scrubber duct at the Elrama Power Plant, in accordance with Cannon's proposal. Subsequent contract negotiations resulted in a fully funded project through a contract, dated September 21, 1993 and amended on May 16, 1994, entered into by Cannon Technology and the following electric power companies: Duquesne Light Company, Metropolitan Edison Company, Pennsylvania Electric Company, Allegheny Electric Cooperative, Inc., Pennsylvania Power and Light Company and Philadelphia Electric Company. ESA, Inc. was selected as the sub-contractor for emissions testing. The test loop, the ozone generator, the loop instrumentation and ESA's emissions testing trailer were installed at the plant site and start-up procedures, which included instrument calibration and system de-bugging began on June 6, 1994 and was completed on June 14. Following a planned station outage, the regular testing program began on June 23 and was completed on July 22. At the request of Duquesne Light Company, two additional tests were run. A high temperature test was run on July 26 and a test, with lime slurry as the scrubber liquid, was carried out on July 27. 
The test results indicated the following:

- high removal rates of NOx pollutants from the exhaust gases of the coal-fired utility boiler under certain operating conditions,

- the ability of the system to operate at $300 \mathrm{~F}$ (which is the temperature of the exhaust gases leaving the ESPs) with a small penalty in additional ozone consumption,

- that neither carbon monoxide and sulfur dioxide gases or carbon particulates have significant effects on ozone consumption,

- that lime slurry is a suitable absorbent for $\mathrm{N}_{2} \mathrm{O}_{5}$,

- that there is no deterioration of scrubber performance due to the simultaneous absorption of $\mathrm{N}_{2} \mathrm{O}_{5}$ and $\mathrm{SO}_{2}$ in either $\mathrm{NaOH}$ solutions or lime slurries.

- the effect of the $\mathrm{pH}$ of the scrubber liquid on the absorption of NOx is negligible.

- the principal constituents of the scrubber effluent, calcium and magnesium sulfites and nitrates are both useful and possibly economically exploitable.

- the SOx scrubbers for coal fired utility plants act as ozone distracters since ozone oxidizes the sulfites to sulfates.

- Stone and Webster's economic evaluation of the Cannon LTO process, applied to a full scale retrofit installation at the Elrama Power Station, reported a cost effectiveness for NOx removal at $\$ 2230$ to $\$ 3130$ per ton of NOx removed. With the recovery of nitrates, saleable as fertilizer, the cost could be reduced to as low as $\$ 1200$ to $\$ 1400$ per ton of NOx removed.

\subsubsection{Extension of SCAQMD Contract}

On May 19, 1994, two amendments to the original contract with SCAQMD extending the time of project performance through April 28, 1995 were received by Cannon. The amendments expressly exempted SCAQMD from further financial obligation beyond that set forth in the original contract. 


\subsection{FINANCIAL SUMMARY}

\subsection{Overview}

The contracted price for completion of the Demonstration was $\$ 356,251.00$. These funds were to be shared among five (5) interested parties in the following distribution:

U.S. DOE (Pittsburgh Energy Technical Center)

Southern California Gas Company

Alta Dena Dairy, City of Industry, CA

Southern California Air Quality Management District

Cannon Technology (Division of Cannon Boiler Works)

Total
$\$ 90,000$

60,000

60,000

30,000

$\underline{116,251}$

$\$ 356,251$

On September 29, 1993, the end of the contract period, the expenses had accrued to the amounts shown:

Engineering Costs

$\$ 23,046$

Shop Labor

Sub-total Labor

25,809

$\$ 48,855$

Fringe Benefits

12,702

Sub-total Salaries and Wages

$\$ 61,557$

Procurement

193,409

Miscellaneous

1,500

Contractual

36,460

Total before General and Administrative

$\$ 292,926$

General and Administrative (30.6\%)

89,635

Grand Total

$\$ 382,561$

Budget

356,251 
The contribution of each participant and their share in per cent was as follows:

U.S. DOE

SoCalGas

Alta Dena Dairy

SCAQMD

Cannon Technology

Totals
$\$ 90.000$

60,000

60,000

$27,000^{*}$

$145,561^{* *}$

$\$ 382,561$
$23.5 \%$

15.7

15.7

7.1

$\underline{38.0}$

Notes: * SCAQMD paid only $90 \%$ of its original commitment. The remainder is being held until project is completed.

** The amount of $\$ 26,310$ which was the excess of expenses over the original estimate (contract price), and all subsequent expenses until October 1994, were absorbed by Cannon Technology. As of May 31, 1994 the excess stood at $\$ 87,637$ making Cannon's total contribution to the project $\$ 202,714$.

\subsection{Close-out Financial Forms}

The following relevant documents are found in Appendix C:

Copy of Standard Form 424A, Budget Information from DOE Award document. Standard Form 269, Financial Status Report

Standard Form 270, Request for Advance or Reimbursement

Table 1, spreadsheet showing each participants portion of expenses

\subsection{New Financing For Project Continuation}

From December, 1993 until September of 1994, Cannon Technology carried out an active search for the additional funding required to complete the Cannon LTO System demonstration at the Alta Dena Dairy. In September of 1994 arrangements were concluded with two U.S. corporations, who jointly agreed to supply a total of approximately $\mathbf{\$ 2 5 0 , 0 0 0}$ for the completion of all of the remaining tasks in the Statements of Work included in the Pittsburgh Energy Technical Center's Award Agreement DEFC22-92PC92161 with Southern California Gas Company. 


\subsection{PROGRESS REPORT ON ACTIVITIES AFTER SEPTEMBER 29, 1993}

\subsection{LTO System Design Changes}

\subsubsection{Overview}

The necessity for re-engineering the LTO system offered real opportunities for drastic improvements. It permitted the lessons learned from the Elrama Slip Stream Test and the Ben Franklin Packed Tower Optimization Study to be incorporated into that design. It also gave additional time for a reconsideration of the data acquisition and control system design and for a final hazmat study. The newly designed system is simpler, smaller, more efficient and more tightly controlled. Fewer technicians will be required for running the test program. The system will require less maintenance and operate more reliably than the original system. An additional opportunity exists because of the addition of a flue gas recirculation system to the Alta Dena boiler. The Cannon LTO system will now be able to operate, as originally planned, with the FGR system deactivated or it can operate as a polishing system with the FGR system in operation.

\subsubsection{Detailed Changes in the LTO System}

After proposed boiler room changes were announced by Alta Dena Dairy, the LTO system was re-engineered. The new P. \& I.D. is found in Appendix A as drawing number D-9000-1A. That drawing reveals the following major changes in the system:

1. The oxygen generating plant has been eliminated. The ozonator will now be supplied with liquid oxygen under a long term contract with a major supplier. A cryogenic storage tank on site will be supplied by truck.

2. The former reactor vessel has been replaced by a 24 inch round duct connecting the condensing economizer with the scrubber vessel.

3. The scrubber has been changed from a two stage, vertical, counterflow spray chamber to a single stage, vertical, packed tower with random packing.

4. The orifice meters for measuring gas flows have been changed to thermal instruments with inherently low pressure drop.

5. The condensate and spent liquor holding tanks, the liquid discharge measuring tank and the neutralizing tank have all been eliminated. $\mathrm{pH}$ control and spent liquor discharge are managed through the packed tower sump with $\mathrm{pH}$ sensors and level controllers.

6. All gas monitoring sensors for measurement and control are now electrochemical cells, which have better response characteristics than chemiluminescent and NDIR monitors. The final test runs for U.S. EPA and SCAQMD approval will be done by a third party contractor using an EPA approved portable laboratory.

7. Liquid discharges from the LTO system will now be routed to the Alta Dena acid treatment station instead of going directly to the sanitary sewer. 
8. The Alta Dena boiler has been fitted with a flue gas recirculation (FGR) system in order to bring the NOx emissions below the State mandated level ( 40 ppmv). That would have been unnecessary had the Cannon LTO Demonstration Project been completed on time. In order for the Alta Dena Dairy to continue operation after September 29, 1993, it became necessary to bring the plant into compliance with current regulations. That was accomplished by retrofitting the boiler with the FGR system. The Cannon LTO system will be capable of operating with or without the FGR system being activated.

\subsection{Changes in Test Protocol}

\subsubsection{Overview}

The test program will proceed practically unchanged from that set forth in the SCAQMD Work Statement found in Section 5.0, Tasks 4 through 7 . All of those tasks will be performed with the FGR system on the boiler disabled. This will be accomplished by deactivating the FGR fan. Additional tests will be run, however, with the FGR fan reactivated. Under these conditions the Cannon LTO System will be operated as a polishing system, removing as much of the boiler generated NOx as is possible.

\subsubsection{New Test Protocol}

A copy of the latest draft of the test protocol is found in Appendix D.

\subsection{New Project Schedule}

The latest draft of the new test schedule is found as the GANTT charts in Appendix E. 


\subsection{CONCLUSIONS}

The conclusions that were drawn from this project, to date, are:

1. The original project cost estimates were badly underestimated. They were based upon Cannon's experience as a manufacturer of thermal systems, but evidently did not take sufficiently into account the remaining development costs that would accrue, the cost of engineering and project management of a totally new and untried system, and the costs associated with administering government contracts and complying with California's air quality and construction regulations. Thus the project was seriously underfunded during the period of the Contract.

2. No financial contingency items were built into the original budget, so that when changes were made in the Alta Dena boiler room, the costs of reengineering the LTO system for those changes were unfunded.

3. The outstanding success of the Elrama Power Station Demonstration, under much more severe conditions than those existing at Alta Dena, inspires a great deal of confidence in obtaining a favorable outcome for the Alta Dena demonstration.

4. The demonstration at Alta Dena will be more informative than originally planned, since the Cannon LTO System will be tested as both a primary NOx control system and also as a polishing system.

5. The project is now on the new schedule (for the new schedule see Appendix F) and will remain on that schedule for testing to begin on May 2, 1995. 


\subsection{RECOMENDATIONS}

The next logical step to be taken in the further development of the Cannon LTO System for NOx and SOx reduction is to retrofit a full scale system to a utility plant. Because the Cannon LTO System can share an existing wet desulfurization scrubber with the power station, with no significant modifications required and with no deleterious interaction occurring between the sulfite/sulfate and nitrate absorptions, the demonstration platform to be selected should be a power station with a wet scrubber desulfurization system. Leading candidates should be plants owned by those utility companies that sponsered the Elrama Slip Stream Test Project (refer to Section 6.3.3) since they are familiar with the results of those tests and because those companies face a drastic downward revision of their existing NOx emissions regulations following an expected recommendation of the Northeast States Ozone Transport Board. It is generally accepted that the required reduction in NOx emissions will be from a present level of $0.6 \mathrm{lb}$ of $\mathrm{NO}_{2}$ per million BTUs of thermal input to 0.25 or $0.20 \mathrm{lb} / 10^{6} \mathrm{BTU}$.

The Report on the Elrama tests gave an estimate of costs for a full scale Cannon LTO System, for a utility plant with wet scrubbers, that varied from approximately $\$ 2000$ to $\$ 3000$ per ton of NOx removed. That cost would be reduced if the LTO system were used as a polishing system, combined with one or more other less expensive but less efficient NOx reduction systems. Included among the possibilities are low NOx burners, SNCR systems, carbon reburn systems, natural gas injection system, etc. It appears that an economic study of the optimum use of the LTO system as a polisher should precede any full scale utility plant demonstration.

The Report also raises the strong possibility that the Calcium Nitrate might be recoverable from the scrubber and processed economically for sale. Cannon's present estimate is that for he Elrama Power Station that the $\mathrm{Ca}\left(\mathrm{NO}_{3}\right)_{2}$ yield could be as great as 17,900 tons per year. The present bulk market price in this area is over $\$ 1000.00$ per ton. A feasability study should be done in conjuction with the LTO system study to determine the net costs and benefits of the LTO system use in large electric power plants. There are indications that the processing and sale of byproducts could easily result in a cost for NOx reduction as low as $\$ 1200$ per ton of NOx removed. 
1. ORIGINAL P. \& I.D.

2. LATEST P. \& I.D. 


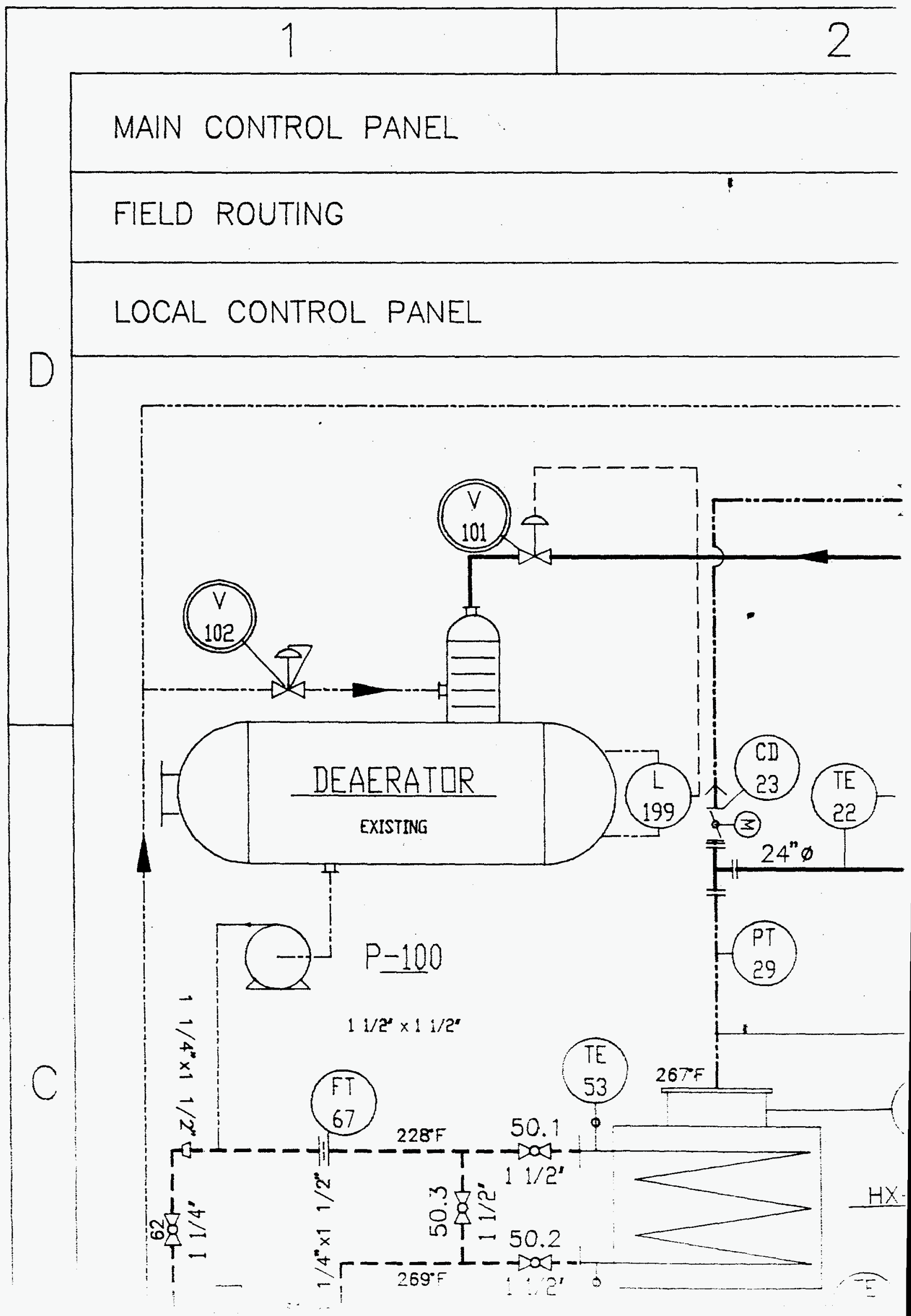



2
3

$>$ TD ATMLSPHERE 


\section{4}

\section{5}

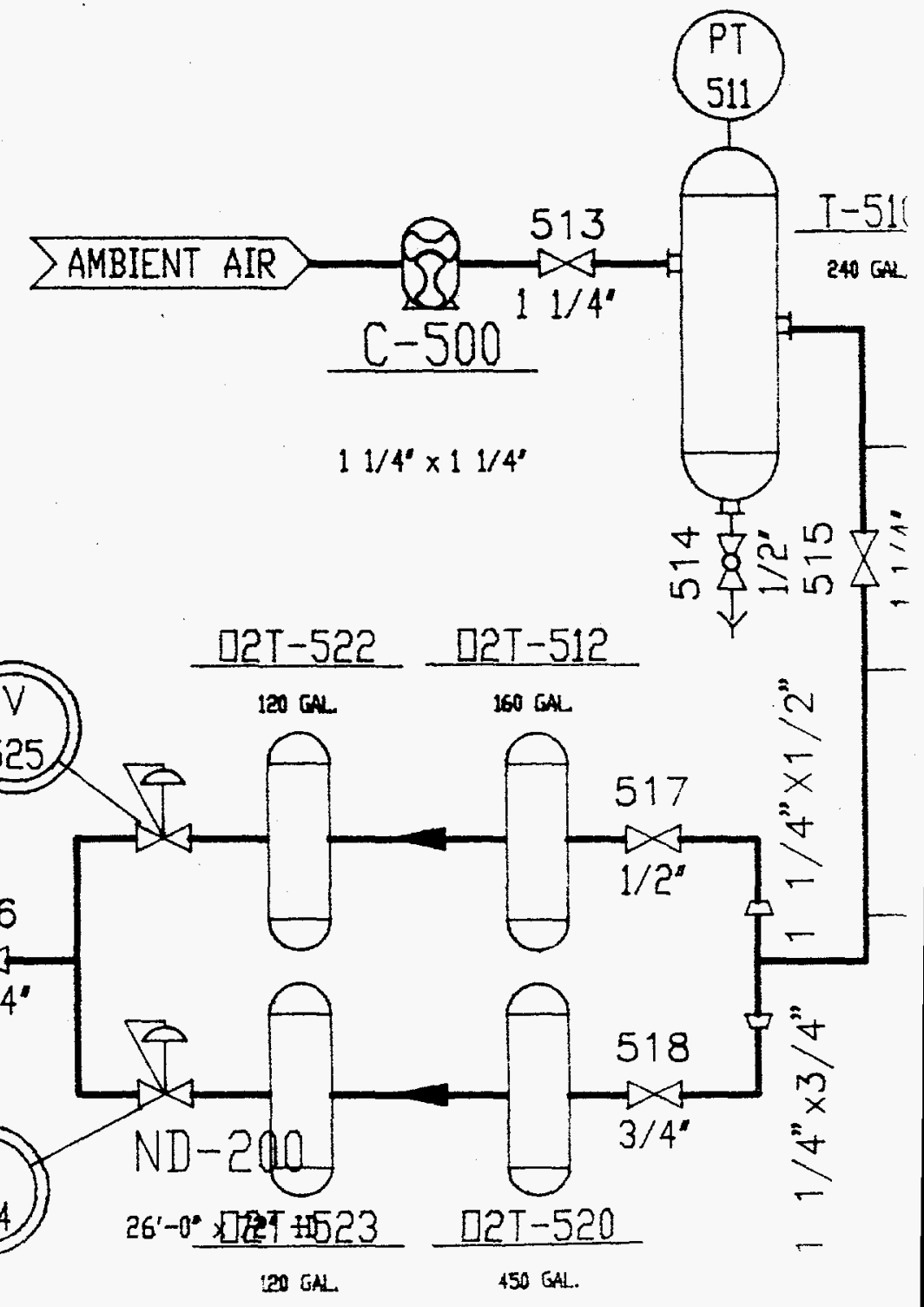




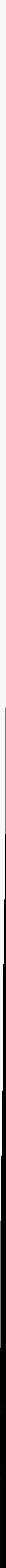




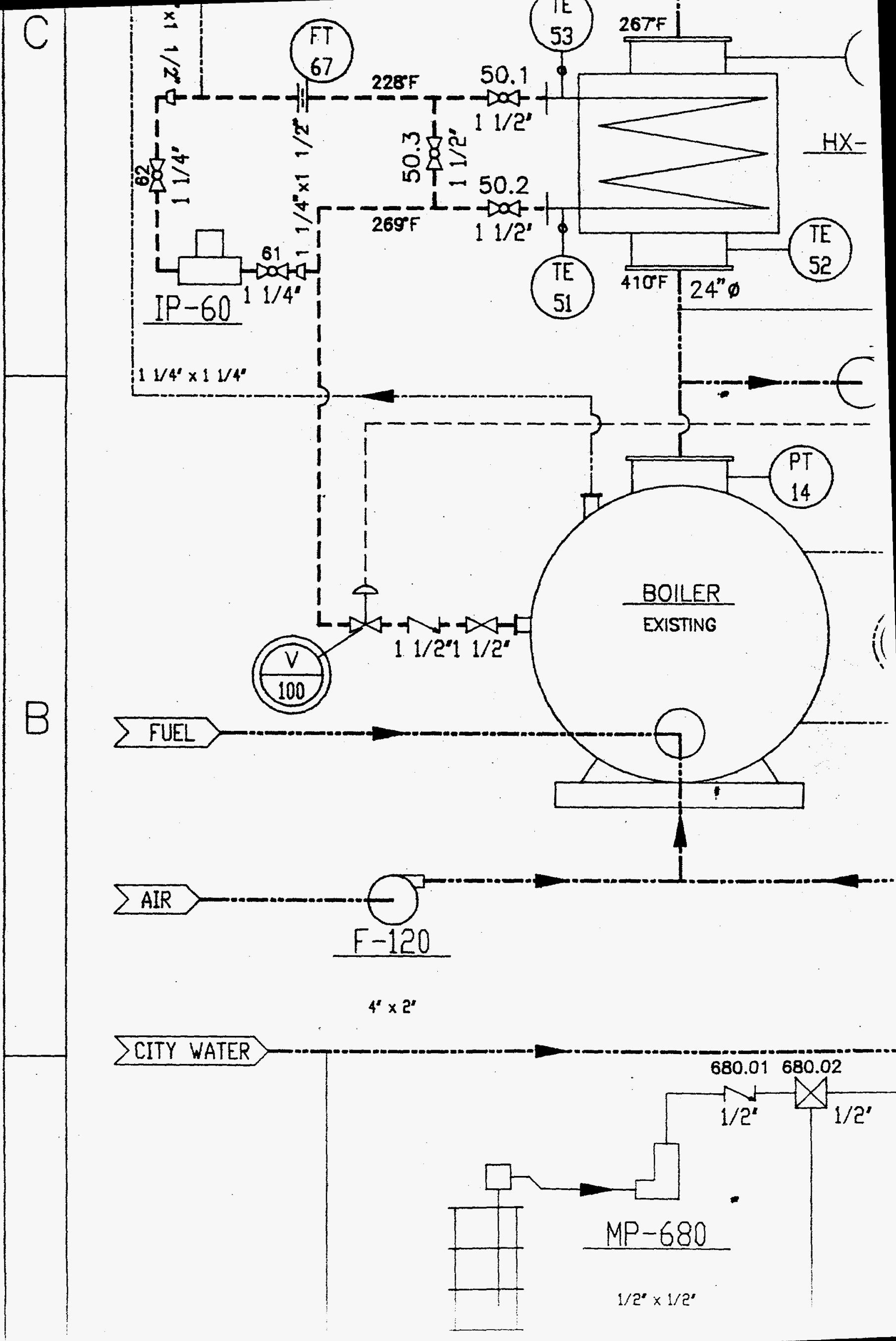




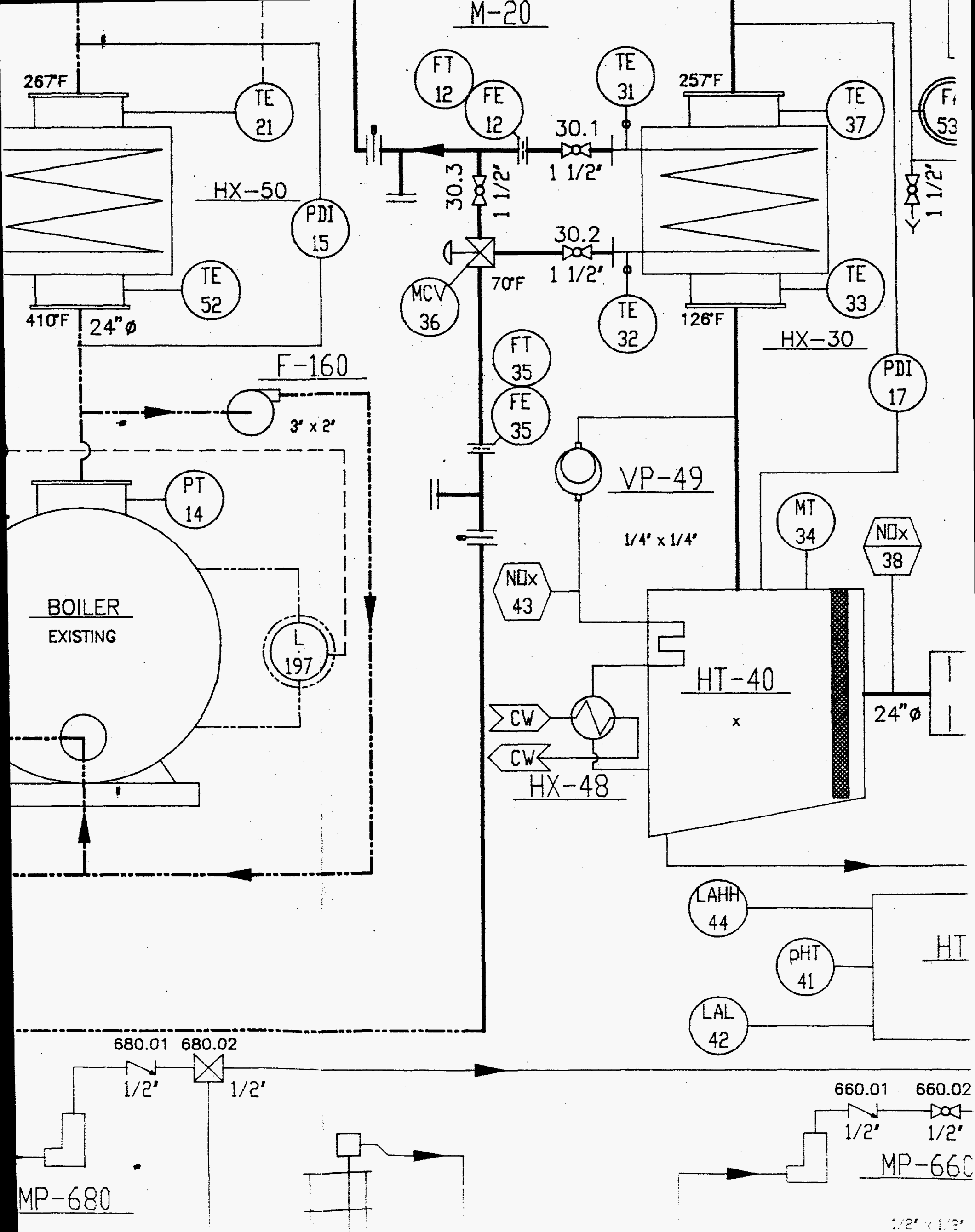




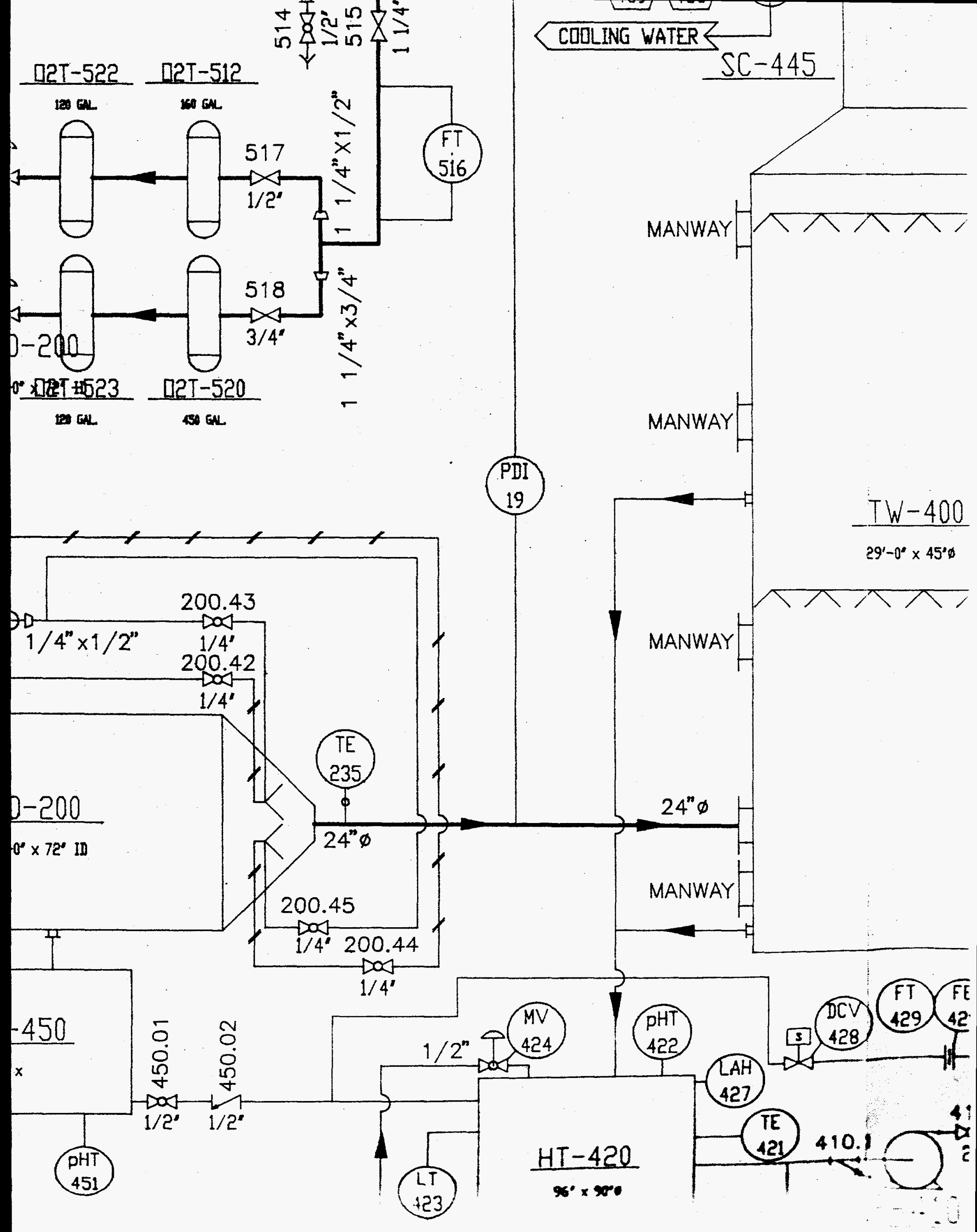




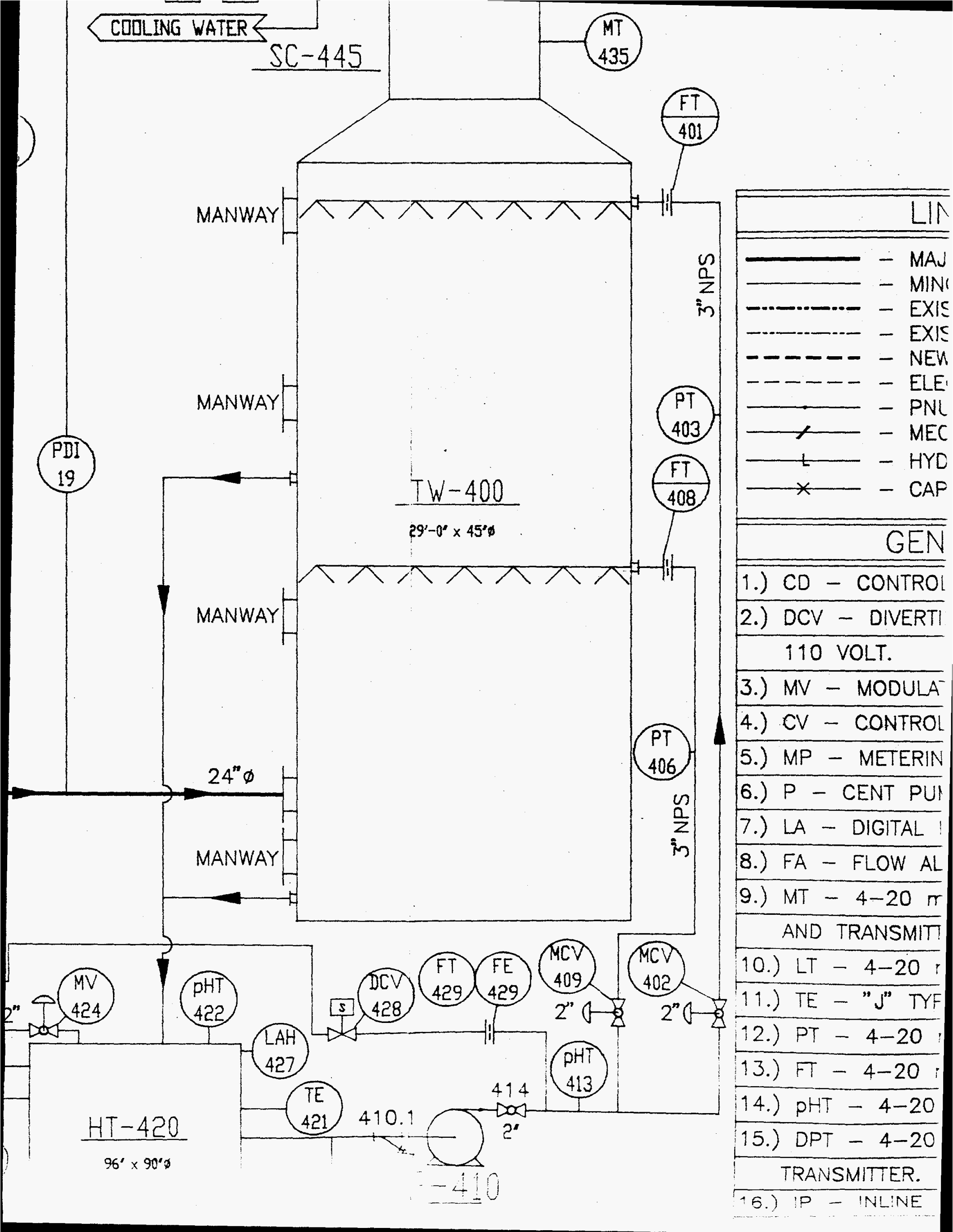





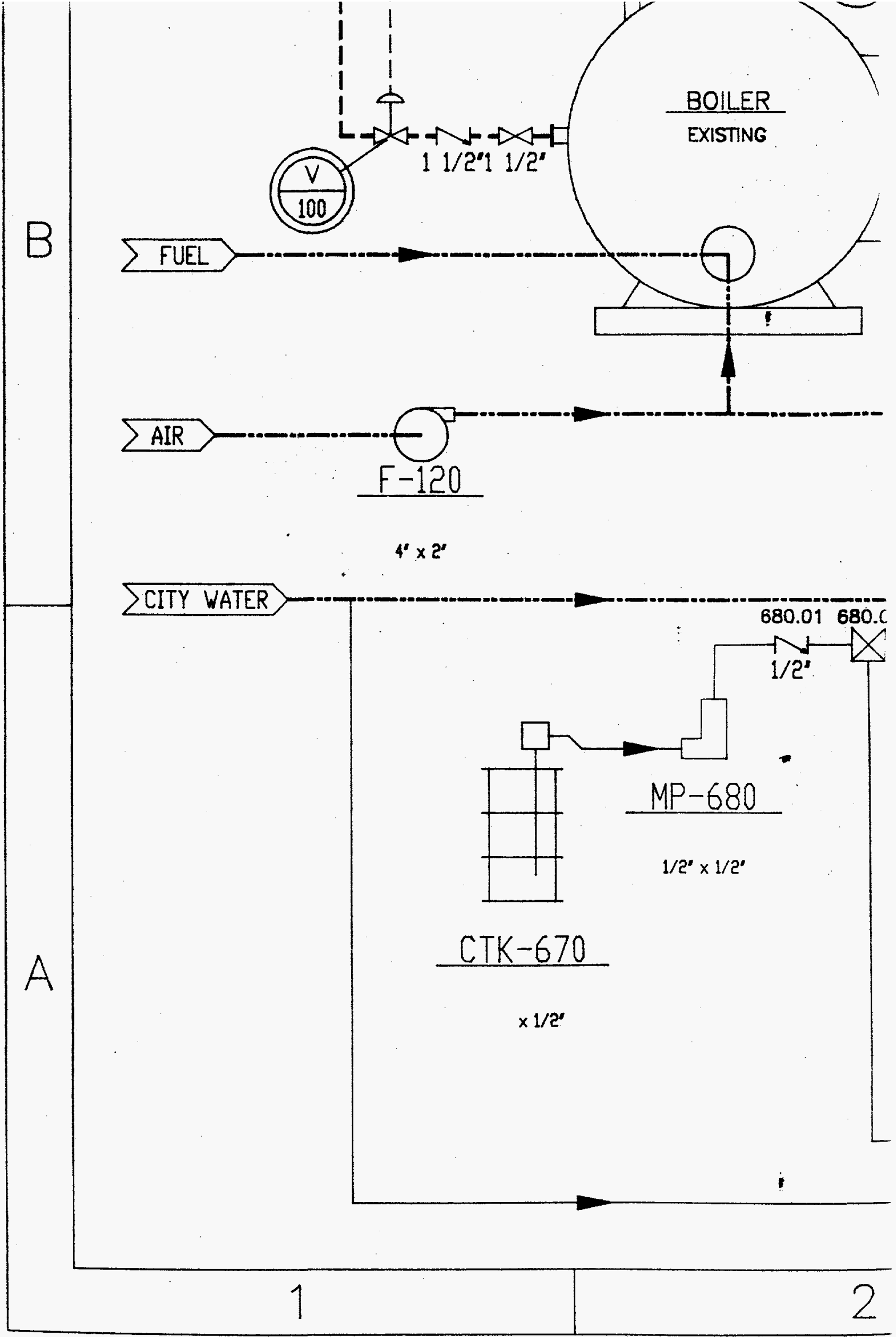




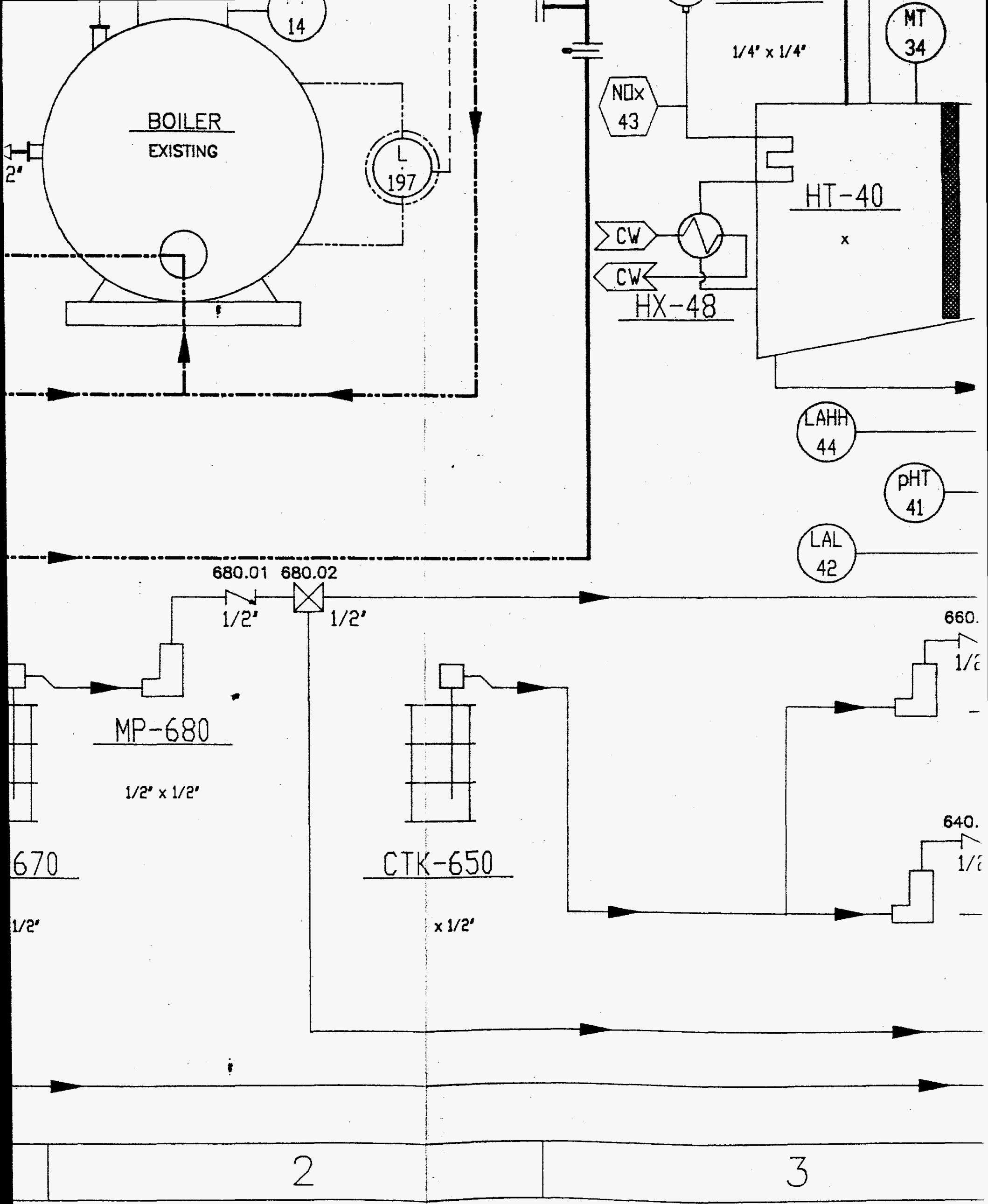




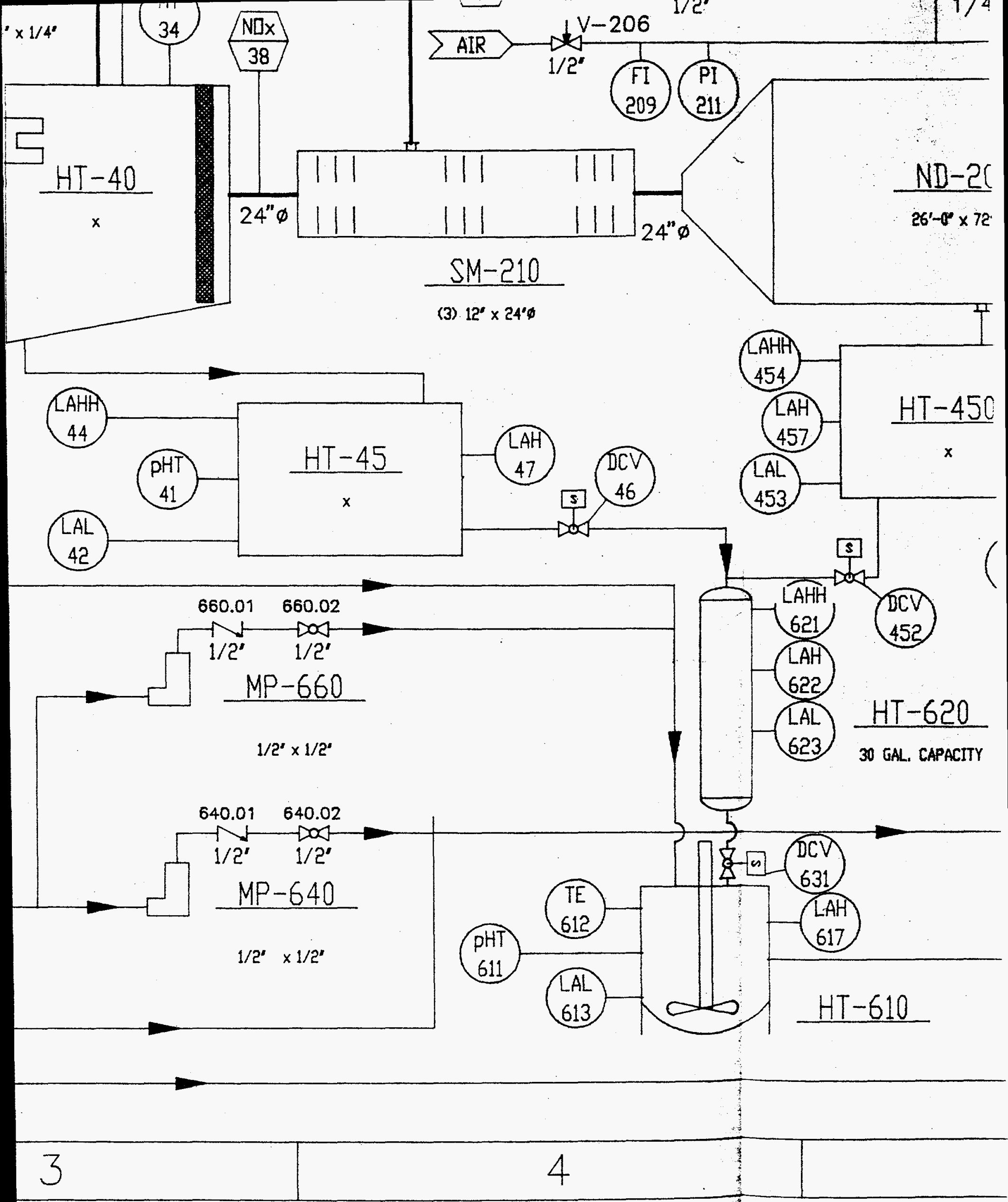




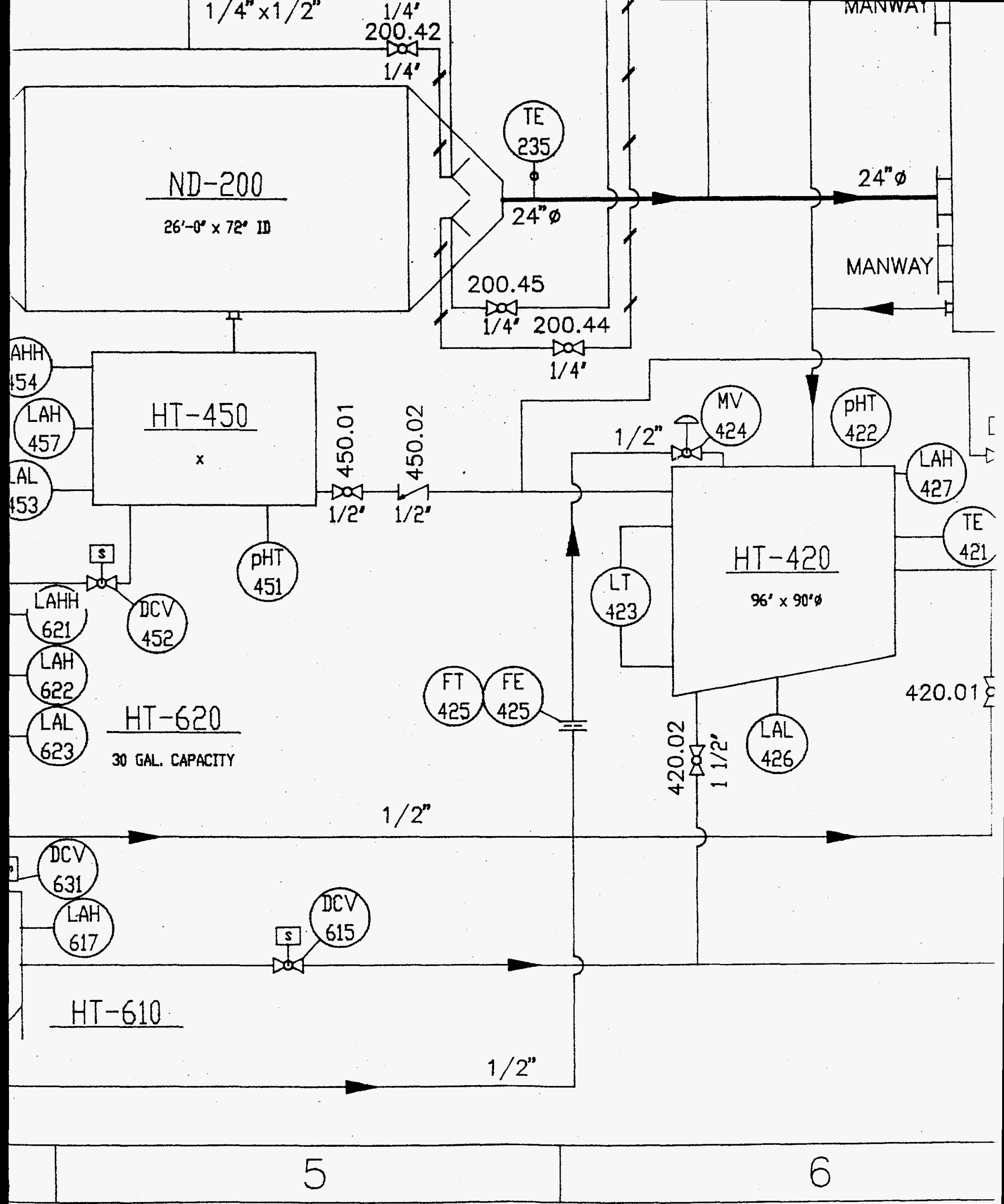




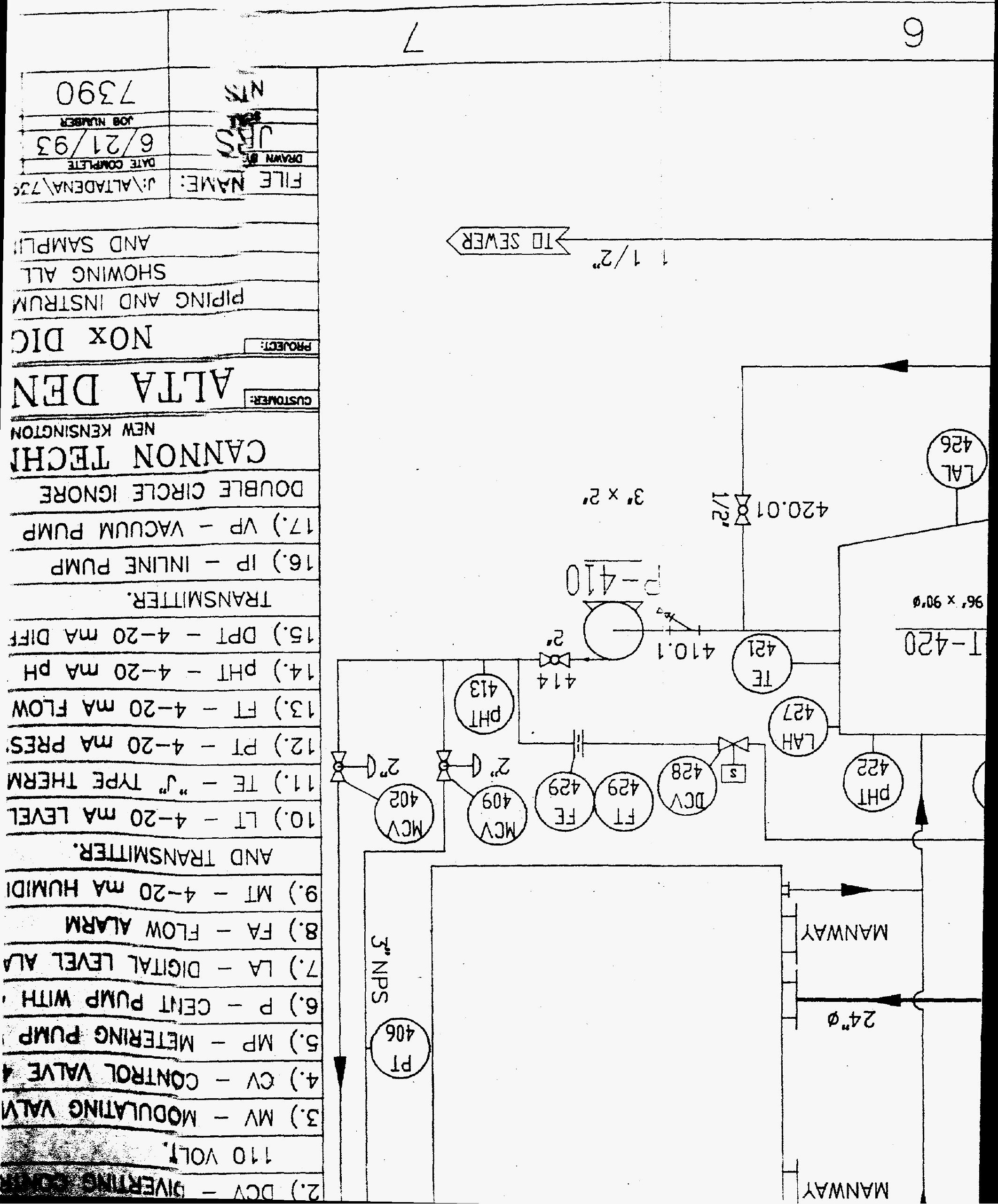


2.) DCV - DIVERTING CONTROL VALVE SWITCHED 110 VOLT.

3.) MV - MODULATING VALVE 4-20 mA INPUT.

4.) $\mathrm{CV}$ - CONTROL VALVE 4-20 WITH MA INPUT.

5.) MP - METERING PUMP WITH 4-20 mA INPUT.

6.) P - CENT PUMP WITH 4-20 mA PWR METER.

7.) LA - DIGITAL LEVEL ALARM.

8.) FA - FLOW ALARM

9.) MT - 4-20 mA HUMIDITY MONITOR AND AND TRANSMITTER.

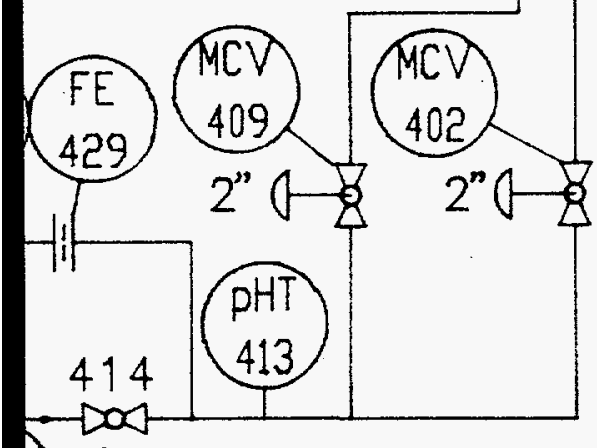

ZTO SEWER
10.) LT - 4-20 mA LEVEL TRANSMITTER.

11.) TE - "J" TYPE THERMOCOUPLE ELEMENT.

12.) PT - 4-20 mA PRESSURE TRANSMITTER.

13.) FT - 4-20 mA FLOW TRANSMITTER.

14.) $\mathrm{pHT}-4-20 \mathrm{~mA}$ pH TRANSMITTER.

15.) DPT - 4-20 mA DIFFERENTIAL PRESSURE TRANSMITTER.

16.) $I P$ - INLINE PUMP

17.) VP - VACUUM PUMP

DOUBLE CIRCLE IGNORE

CANNON TECHNOLOGY, INC. NEW KENSINGTON, PA 15068

CUSTONER:

ALTA DENA DAIRY

NOx DIGESTER

PIPING AND INSTRUMENTATION DIAGRAM SHOWING ALL EQUIPMENT AND SAMPLING POINTS

FILE NAME: $\quad$ J:\ALTADENA $7390-1$. DWG DRAWN BY:

JRS DATE COMPLETE $6 / 21 / 93$ JOB NUMBER DRAMING NUMBER

7390

$D-7390-1$

8 


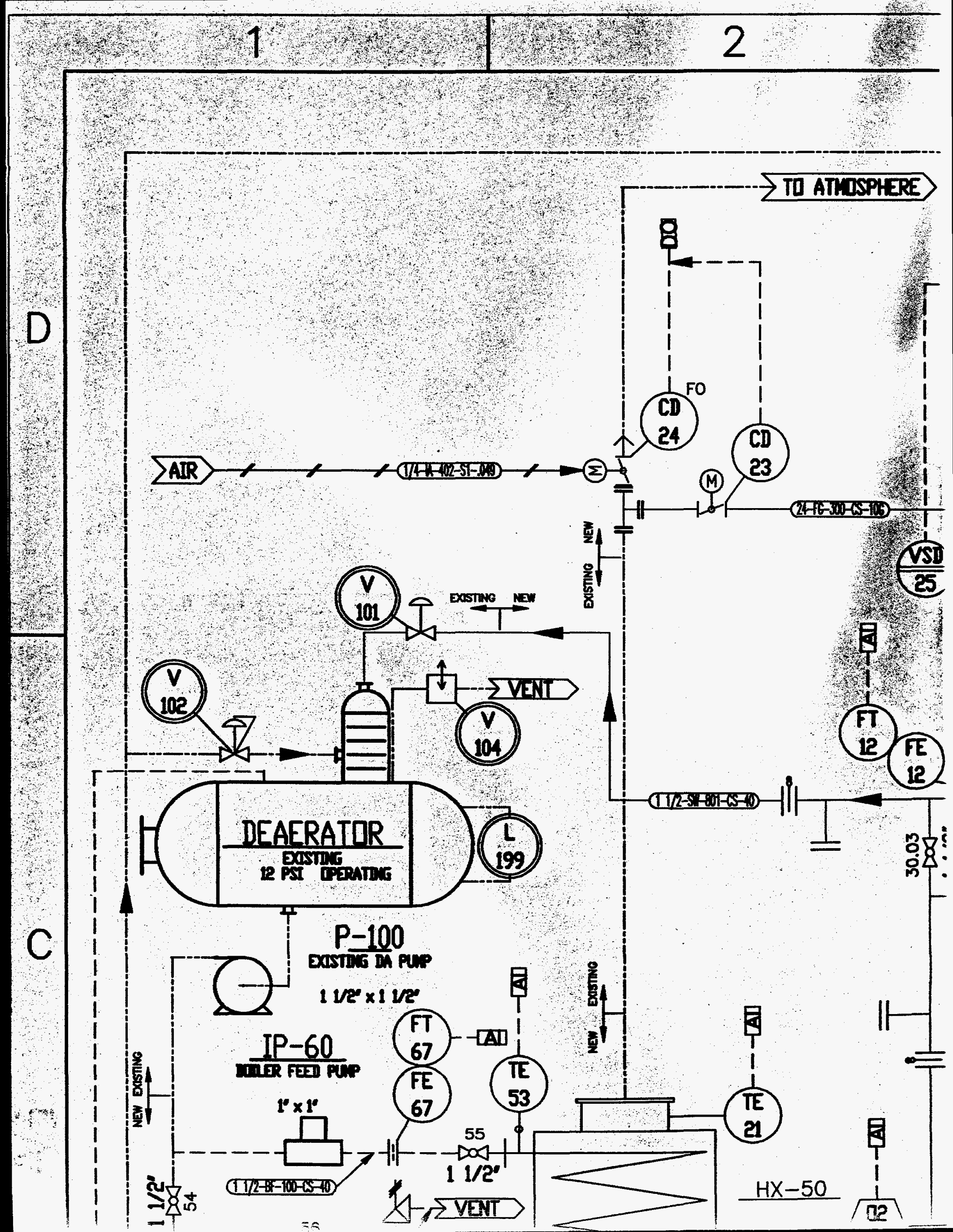




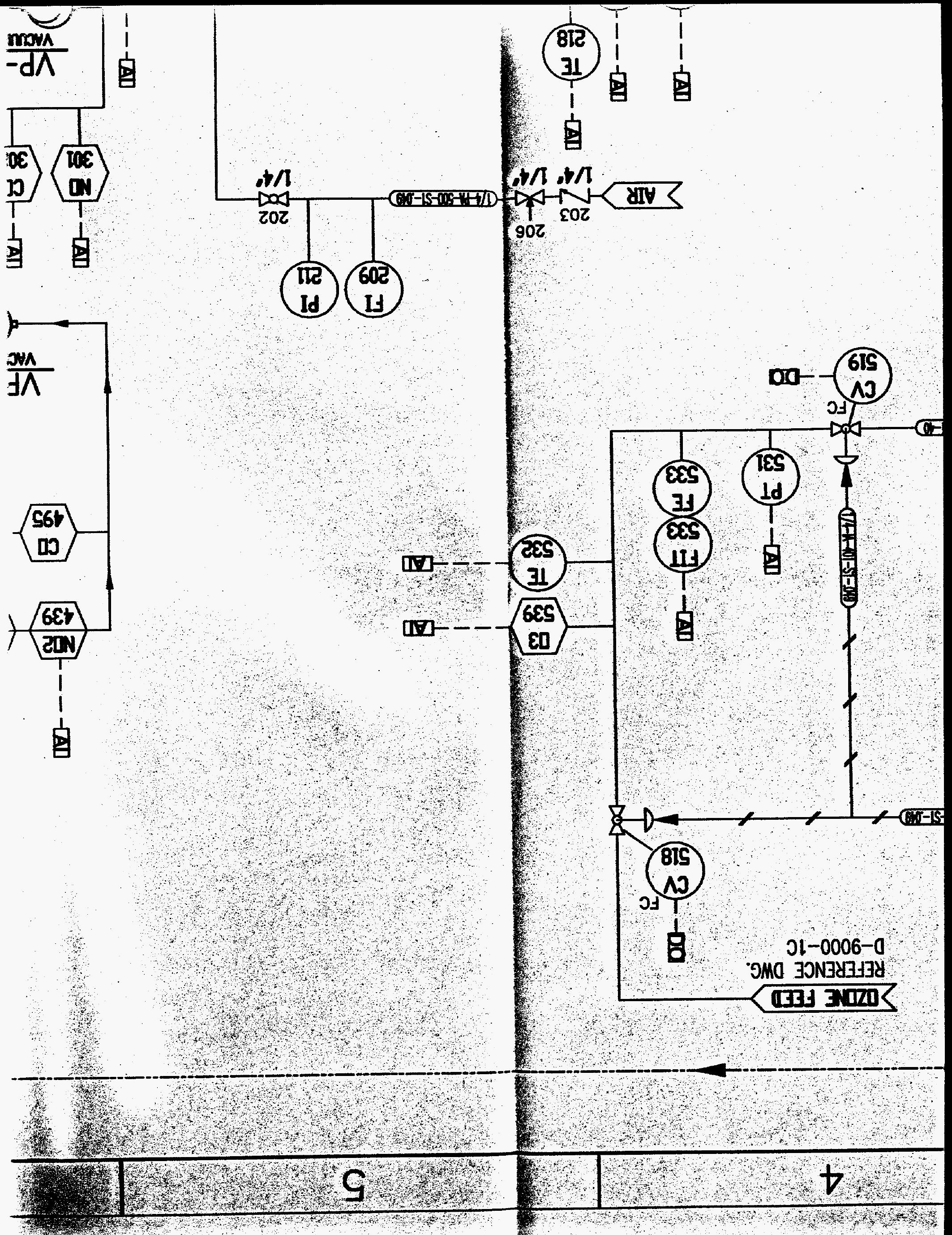




\section{6}
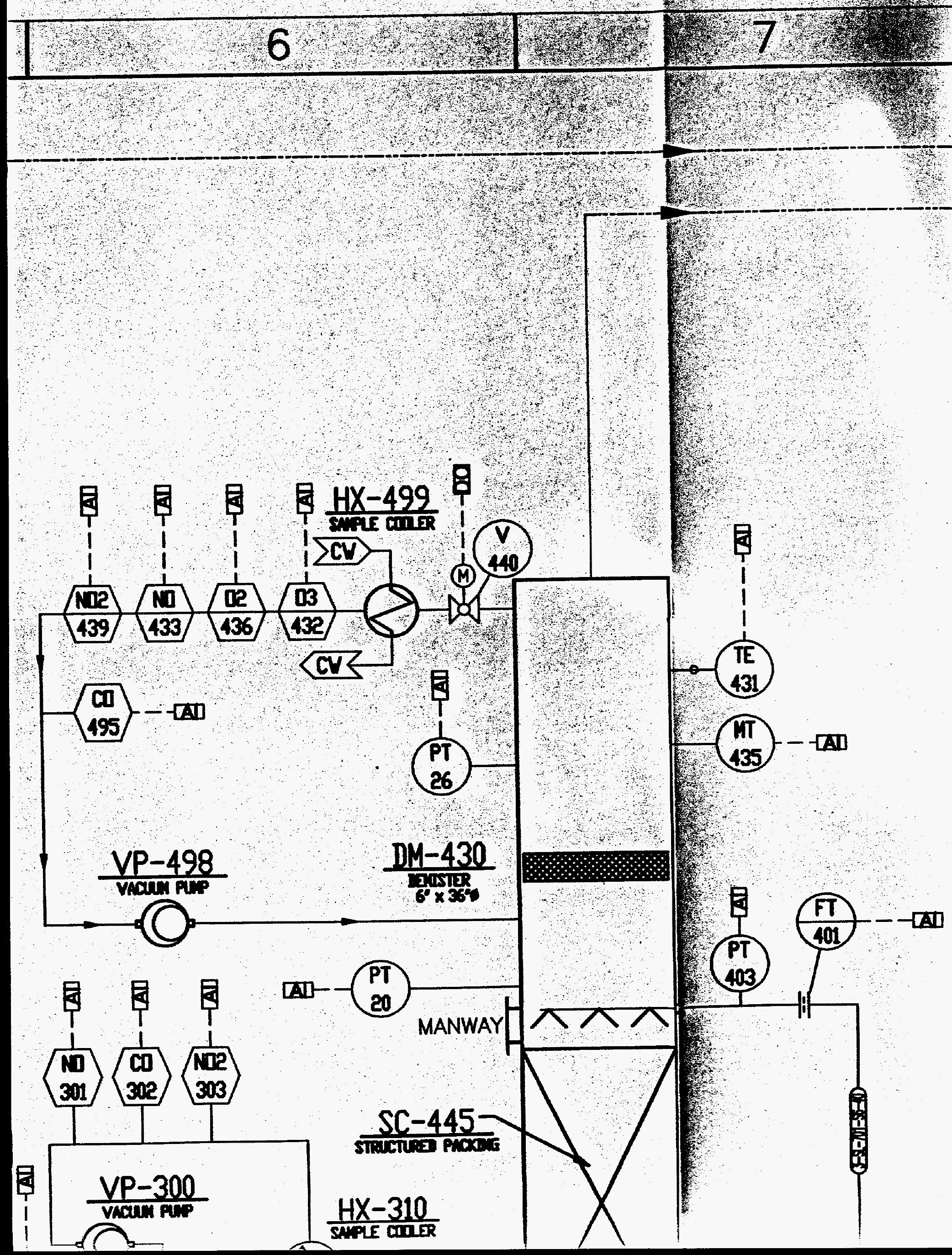


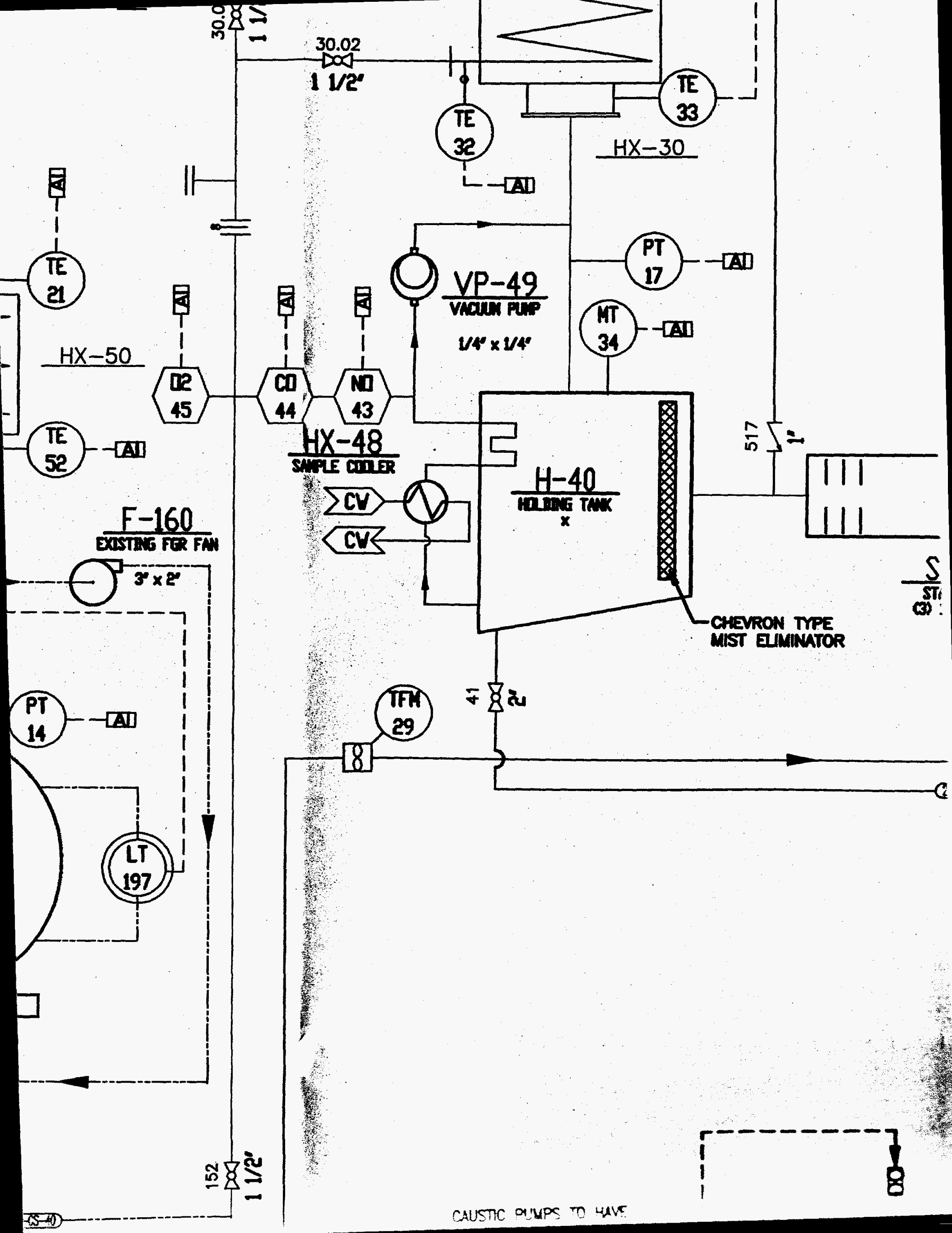




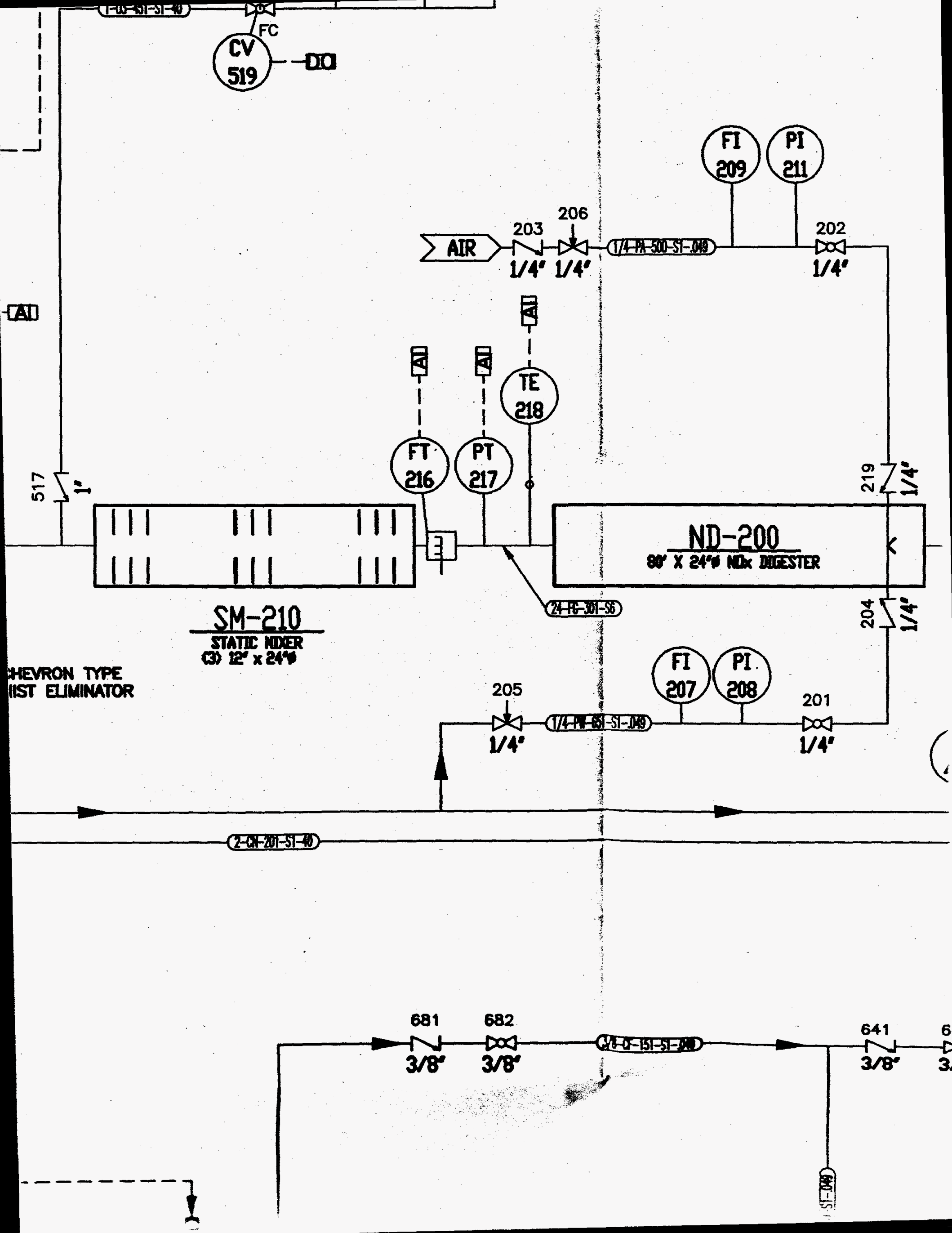




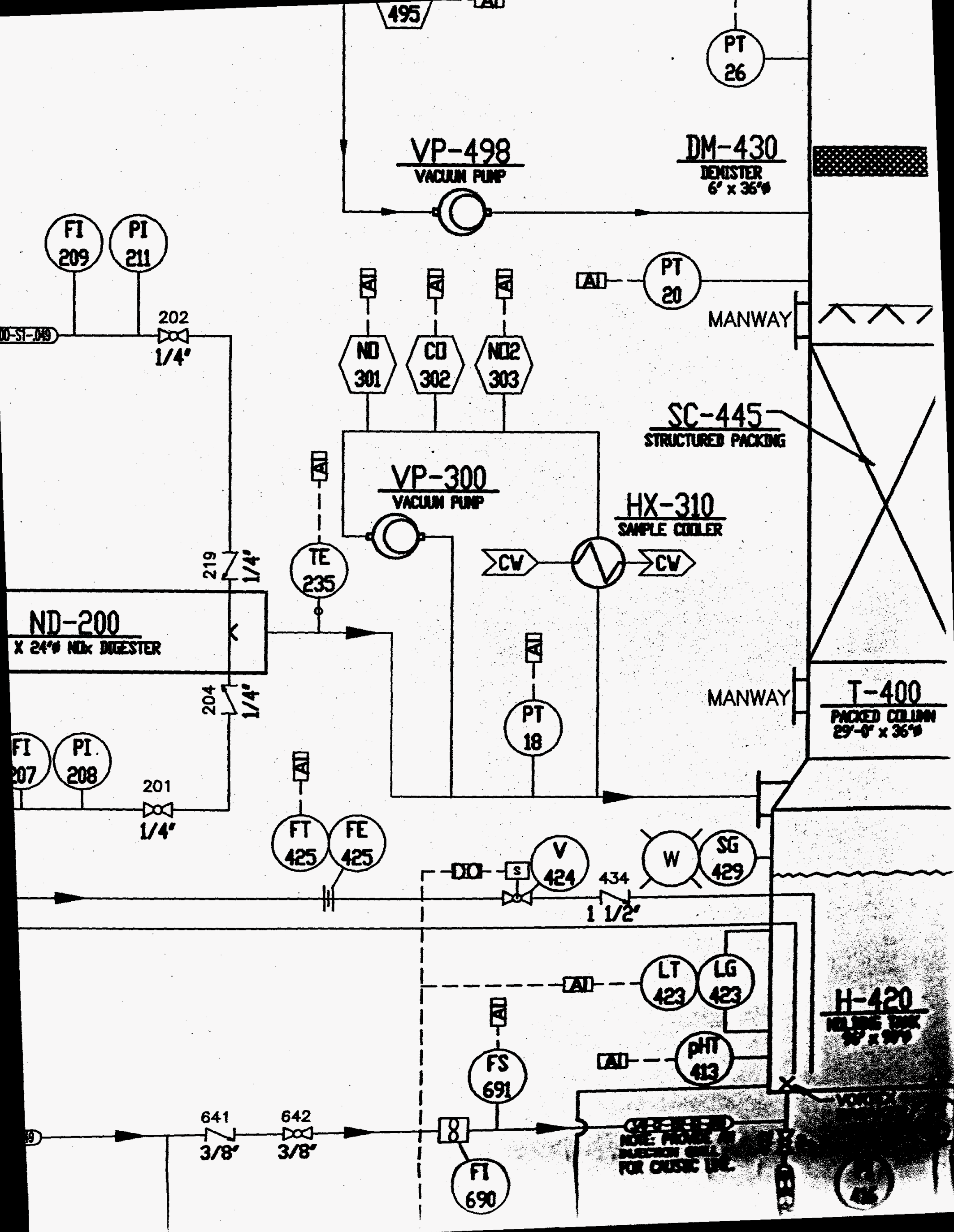




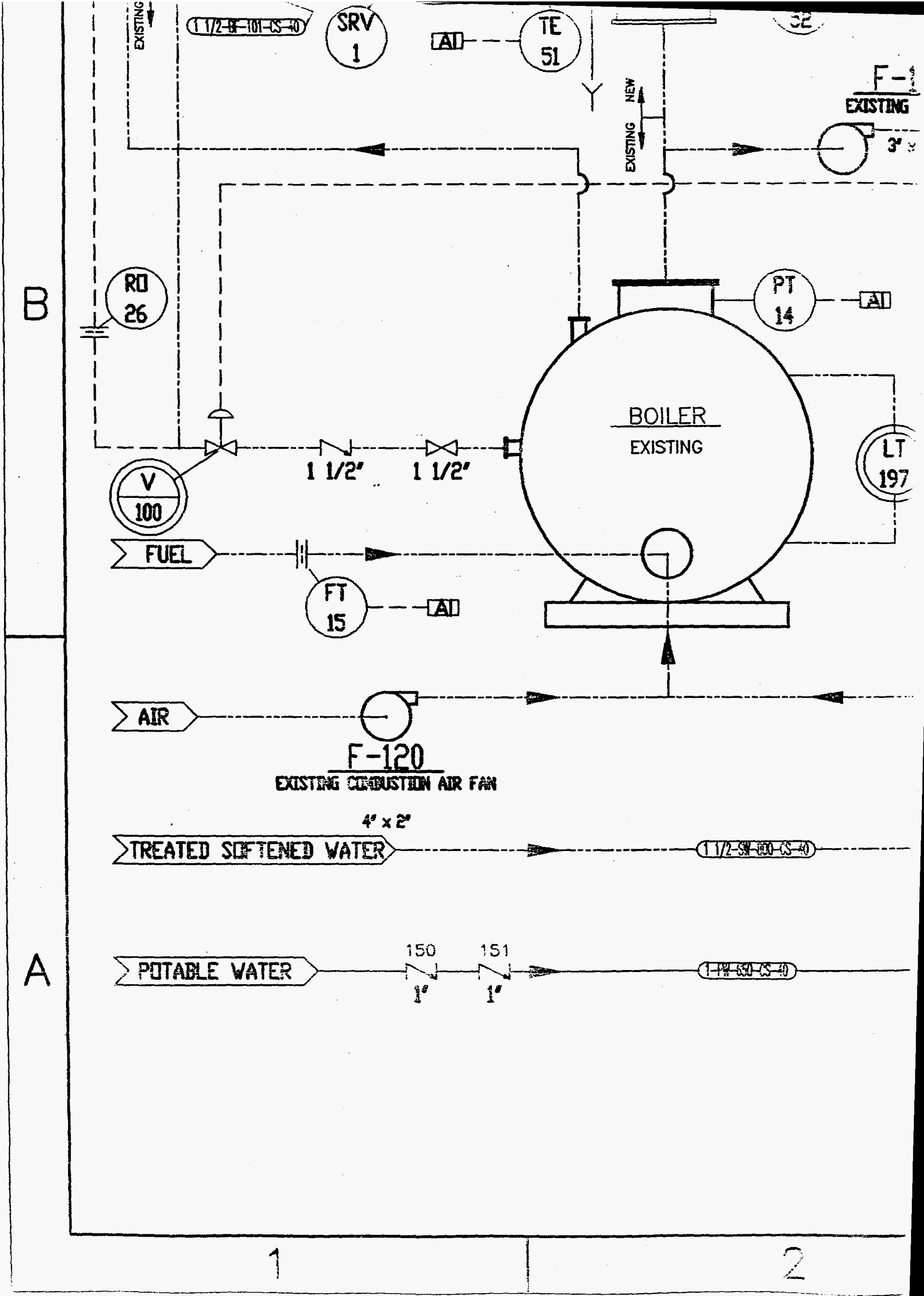




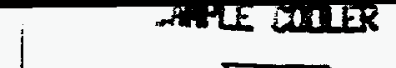




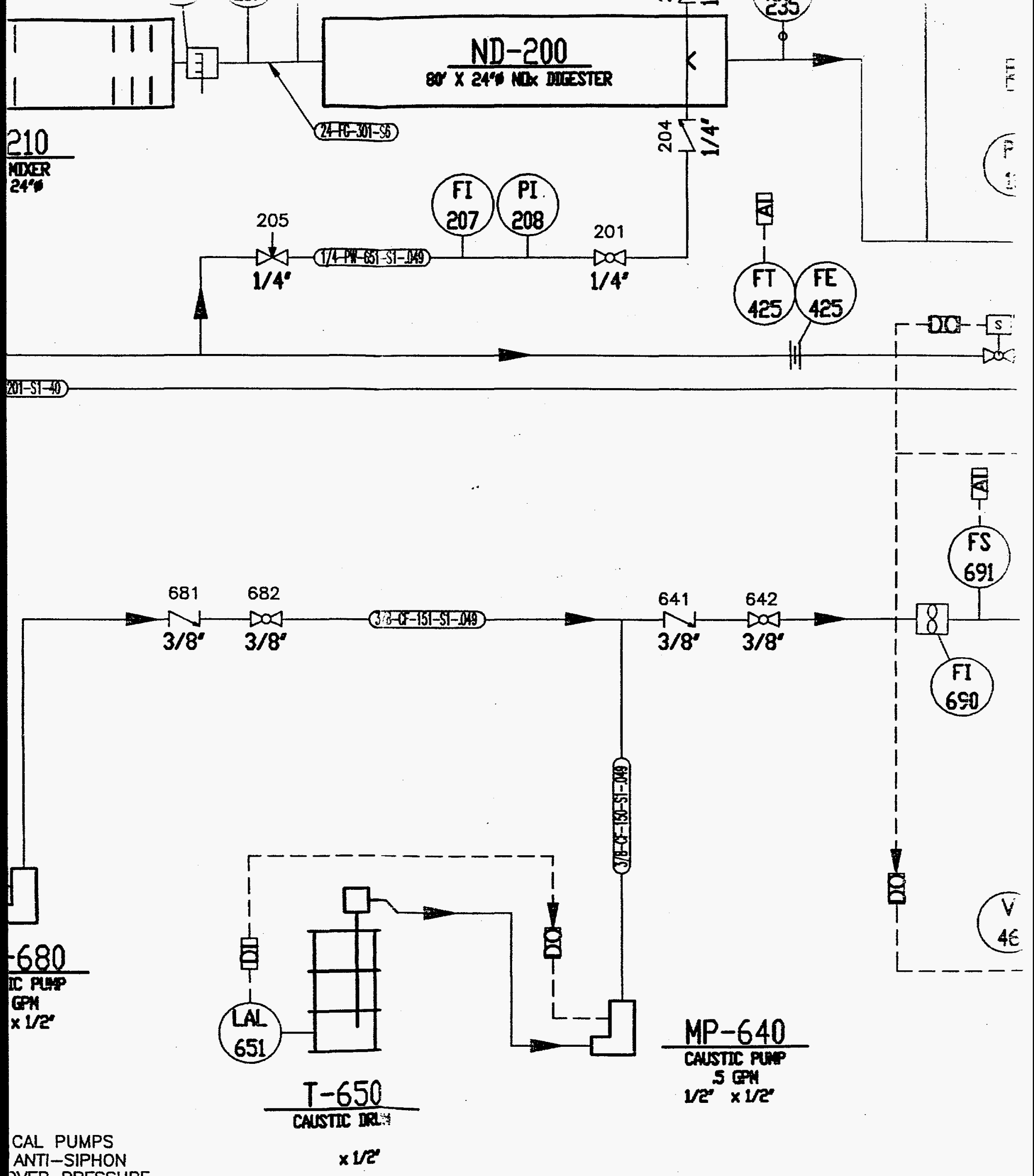

DVER PRESSURE

आILITIES

4 


\section{APPENDIX B}

\section{PROJECT REPORTS}

SEPTEMBER 30, 1992 TO SEPTEMBER 29, 1993 


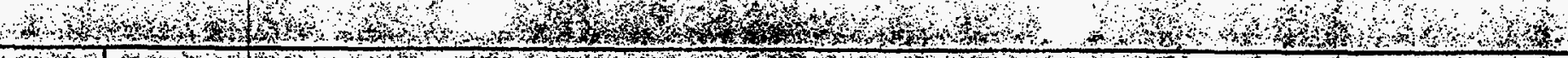

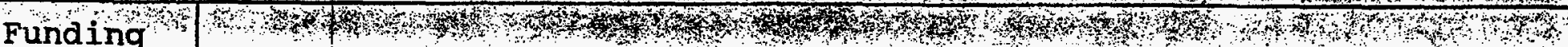

Source

South Coast Air Quality Management District

contract

Number.

Report

Period:
SCAQMMD-S-C93111

$$
9 / 30 / 92 \text { to } 12 / 31 / 93
$$

\section{DE-Fe22-92PC92161}

Project
Title
Report
Author

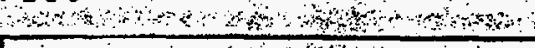

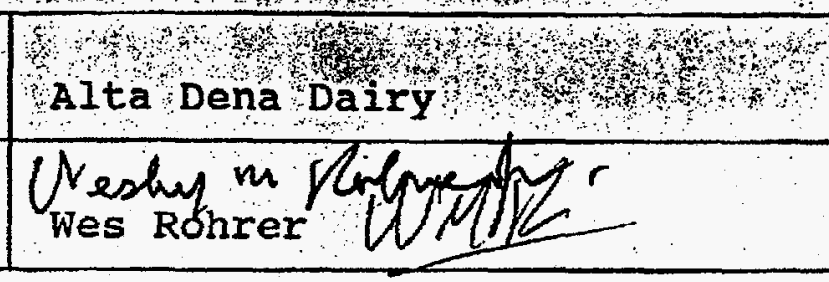

Work completed The following tasks have been completed. 1) Heat \& Mass balances completed. 2) P \& ID completed. 3). Major system components specified and purchase orders sent out. 4) Fan, oxygen plant, ozone generator completed and awaiting shipment. 5) Heat exchangers being fabricated in cannon's shops. 6). Design completed for reaction chamber, spray chamber and packed tower. 7) Nozzles, valves and instrument sensors have ben specified. 8) General arrangement has been specified. 9) Three visits to Alta Dena Dairy.

Work Planned 1) Complete all remaining purchase orders and send to vendors. 2) Complete the General Arrangement drawing. 3) Complete fabrication of Heat Exchangers, reaction chamber, spray chamber and packed tower. 4) Design ducting and piping. 5) Complete control system design; 6) Assemble equipment skids for shipment. 7) Begin writing start-up Manual, Operations Manual \& Testing Manual.

Time schedule status on-time according to our Gantt chart. No bottlenecks foreseen. 
- Cannon Project Progress Ronort

Funding

Source

Contract

Number

Report

Period
South Coast Air Quality Management District

\begin{tabular}{|l|l|}
$\begin{array}{l}\text { Project } \\
\text { Title }\end{array}$ & Alta Dena Dairy \\
\hline $\begin{array}{l}\text { Report } \\
\text { Author }\end{array}$ & Wes Rohrer
\end{tabular}

Work Completed The following work was complete on March 1, 1993: 1) Two visits to Alta-Dena Dairy, 2) $P$ and ID for instrument and control system completed, 3) Instruments are specified, 4) High temperature economizer fabrication complete, 5) Spray manifolds designed, 6) Fan delivered, 7) oxygen supply ready for shipment, 8) ozonator nearing completion.

Work Planned

1) Complete all purchasing, 2) Fabricate condensing economizer 3) Fabricate oxidation and spray chambers, 4) Install high temperature economizer at Alta-Dena, 5) Design ducting and piping, 6) Complete general arrangement drawing, 7) Fabricate ducting and piping, 8) Fabricate control panel, 9) Write start-up manual, 10) Begin Operations and Testing Manuals, Assemble equipment skids and shipping crates for shipment.

Time schedule status schedule has slipped about three weeks. We will try to make it up this next quarter. 
- Cannon Project Progress Ranort

Funding

Source

Contract

Number

Report

Period
South Coast Air Quality Management District

\begin{tabular}{l|l}
$\begin{array}{l}\text { Project } \\
\text { Titie }\end{array}$ & Alta Dena Dairy \\
\hline $\begin{array}{l}\text { Report } \\
\text { Author }\end{array}$ & Wes Rohrer W Rahnd) \\
\hline
\end{tabular}

DE-FC22-92PC 92161

$3 / 1 / 93$ to $6 / 1 / 93$

Work completed The following work completed on June 1, 1993: 1). Completed all purchasing with the exception of same instruments and controls. 2). Complated fabrication of condensing economizer and the oxidation chamber.

3). Ozone generator and oxygen supply completed. 4). Finished design of control system and specified instrumentation. 5). Finished design of spray chamber and packed tower. 6). Started fabrication of spray chamber.

Work Planned (1). Complete all fabrication. 2). Ship all components to Alta Dena. 3). Install complete system. 4). Make equipment checks and attempt system start-up. 5). Write Test and Procedure Manuals. 6). Write control code for digital control system.

\begin{tabular}{l|l} 
Time schedule status & Schedule has slipped approximately 90 days partly due
\end{tabular} to delays in transfer of funds from support agencies. 
Funding

Source

contract

Number

Report

Period
South Coast Air Quality Management District

DE-FC22-92PC 92161
$6 / 1 / 93$ to $7 / 31 / 93$

\begin{tabular}{|l|}
\hline $\begin{array}{l}\text { Project } \\
\text { Title }\end{array}$ \\
\hline $\begin{array}{l}\text { Report } \\
\text { Author }\end{array}$ \\
\hline
\end{tabular}

Alta Dena Dairy

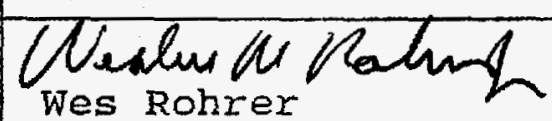

Work Completed

The following work was completed in the period ending

7/31/93: 1). A11 components and system design was complete, 2). Oxidation

chamber and all duct fabrication was completed, 3). All materials and

purchased equipment have been requisitioned, 4). The condensing economizer

has been built. 51. First drafts of the Testing Manual and Start-up Manual

have been completed, 6). The Bill of Materials has been completed,

7). General Arrangement Drawings are completed.

Work Planned 1). Complete fabrication of Spray Tower, 2). Assemble equipment skids, 3). Assemble control Panels, 4). Assemble Master control System,

5). Program the digital control code, 6). Write operations Manual, 7). Crate and ship all material to Alta Dena, 8). Install system at Alta Dena Dairy, 9). Carry out test programs, 10). Write reports. 


\section{APPENDIX C}

FINANCIAL FORMS AND REPORTS 


\section{REOUEST FOR ADVANCE OR REIMBURSEMENT}

(See instmections on back)

3. FEDERAL SPONSOAING AGENCY ANO ORGANIZATIONAL ELEMENT TO WHICH THIS REPORT IS SUBMITTEP

0.S. Department of Energy

Pittsburgh Energy Technical Center

6. EMPLOYER IDENTIFICATION 7 7. RECIPIENT'S ACCOUNT NUMBER NUMBER

95-1240705 25-1242492
Approved by Office of Management and Budget, No. 80-RO183

a. "X" ons, or both boxes

TYPE OF

PAYMENT

REQUESTED

$\square$ advance $Q$ REEMTURSE. b. "X" the applicable bos

Q FINAL

$\square$ PARTIAL

DI ACCRUAL

\begin{tabular}{l|l} 
4. FEDERAL GRANT OR OTHER & 5. PARTIAL PAYMENT REQUEST
\end{tabular} BY FEDERAL AGENCY 92161

DE-FC22-92PC

PERIOD COVERED BY THIS REQUEST

\begin{tabular}{l|l}
\hline FROM (month, day, year) & TO (month, day, year)
\end{tabular}

December 1, 1992 December 31, 1992

10. PAYEE (Whore oheek is to be sent is difierent than itom $\rho)$

\section{RECIPIENT ORGANIZATION}

Name

: Southern California Gas Co./

Cannon Technology

555 W. Fifth Street

Nond ste:

Los Angeles, CA 90013-1011

City, stato

and ZIP Conde:

11.

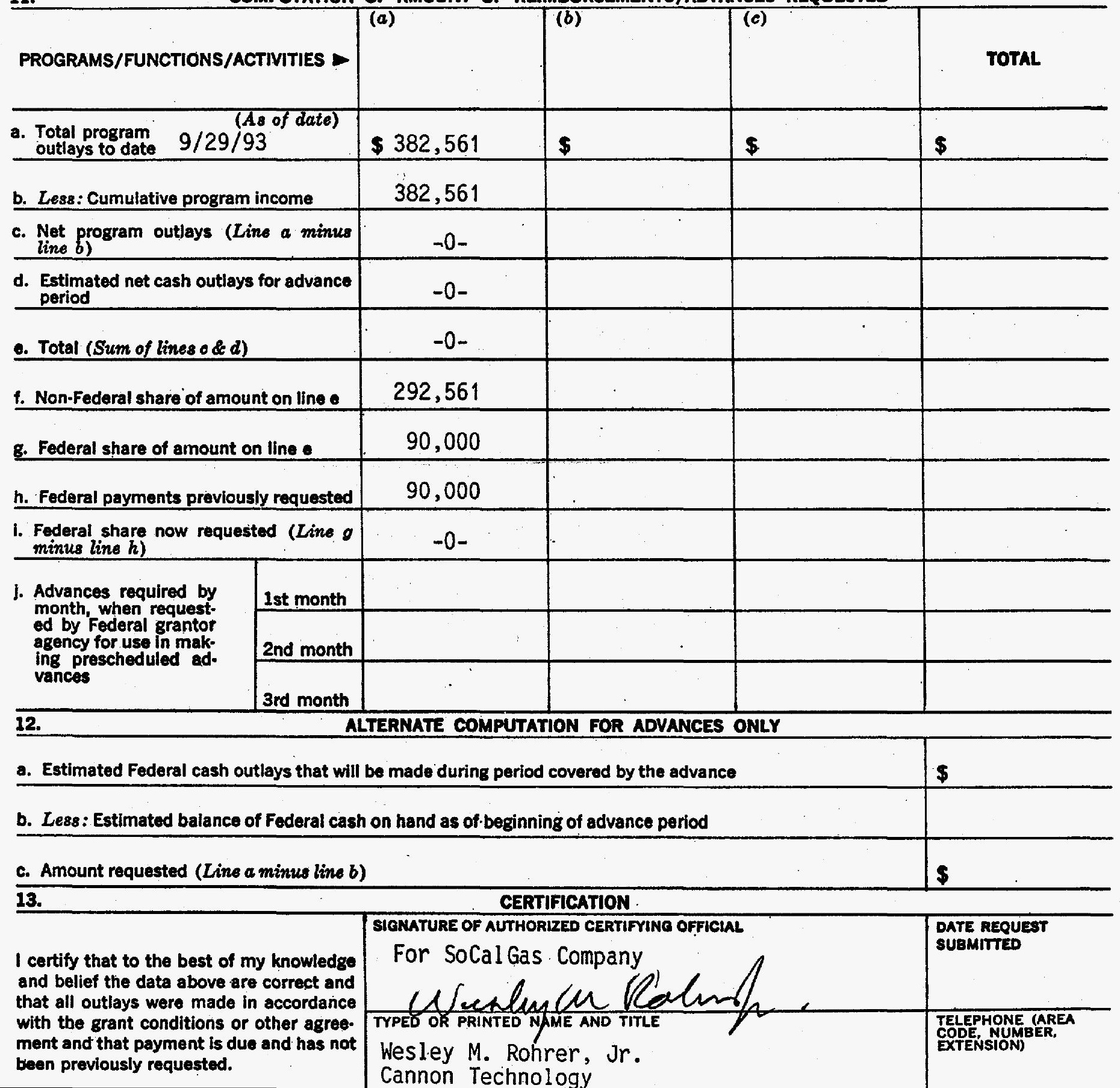


This space for agency use

Prescribad by Office of Management and Budact Cir. No. $\sim-110$ 
FINANCIAL STATUS REPORT

(Long form)

(Follow instructions on the back)

1. Federal Agency and Organizational Element

to Which Report is Subrnitted

U.S. Department of Energy

Pittsburgh Energy Technical Ctr.
2. Federal Grant or Other Identifying Number Assigned By Federal Agency

DE-FC22-92PC-92161
OMB Approval

No. $0348-0039$ of

1 pages

3. Recipient Organization (Name and complete address, including ZIP code)

Southern Cal ifornia Gas Company/Cannon Technology

555 W. Fifth Street

Los Angeles, CA 90013-1011

4. Employer Identification Number

5. Recipient Account Number or Identitying Number

6. Final Repont

[] Yes
9. Period Covered by this Report From: (Month, Day, Year)

To: (Month, Day, Year) $9 / 29 / 93$

From: (Month, Day, Year)

$9 / 30 / 92$

10. Transections:

a. Total outlays

b. Refunds, rebates, etc.

c. Program income used in accordance with the deduction alternative

d. Net outlays (Line $a$, less the sum of lines $b$ and $c$ )

Recipient's share of not outlays, conslating of

e. Third party (in-kind) contributions

f. Other Federal awards authorized to be used to match this award

9. Program income used in accordance with the matching or cost sharing alternative

h. All other recipient outlays not shown on lines $e, f$ or $g$

i. Total recipient share of net outays (Sum of lines $\theta, f, g$ and $h$ )

\section{(-}

j. Federal share of net outlays (line d less line i)

k. Total unliquidated obligations

1. Recipient's share of unliquidated obligations

m. Federal share of unliquidated obligations

n. Total federal share (sum of lines $j$ and $m$ )

o. Total federal funds authorized for this funding period

p. Unobligated balance of federal funds (Line o minus line $n$ )

Program income, consisting of:

q. Disbursed program income shown on lines $c$ and/or $g$ above

P. Disbursed program income using the addition alternative

s. Undisbursed program income

L Tolal program income realized (Sum of lines $q, r$ and s)

$9 / 30 / 92$

Previously Reported

356,251

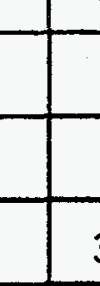

\begin{tabular}{|l|l|}
\hline This Period \\
\hline 26,310 \\
\hline \\
\hline 26,310 \\
\hline
\end{tabular}

7. Basis

DCash D Accrual 
12. Remarks: Attach any explanations deemed necessary or information required by Federal sponsoring agency in compliance with governing legislation.

13. Certification: I certify to the bust of my knowledge and bellef that this report is correct and complete and that all outlays and unliquidated obligations are for the purposes set forth in the award documents.

\begin{tabular}{l}
\hline $\begin{array}{l}\text { Typed or Printed Name and Tite } \\
\text { Wesley } \mathrm{M} \text {. Roh frer, Jr., Di rector of Development }\end{array}$ \\
\hline $\begin{array}{l}\text { Signature of Authorized Certitying Official } \\
\text { For Southern Cal i forni a Gas Co. }\end{array}$ \\
$\begin{array}{l}\text { Previous Editions not Usable } \\
\text { NSN 7540-01-012-4285 }\end{array}$ \\
Prescribed by OMB Circulars A-102 and A-110
\end{tabular}




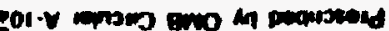

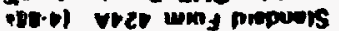

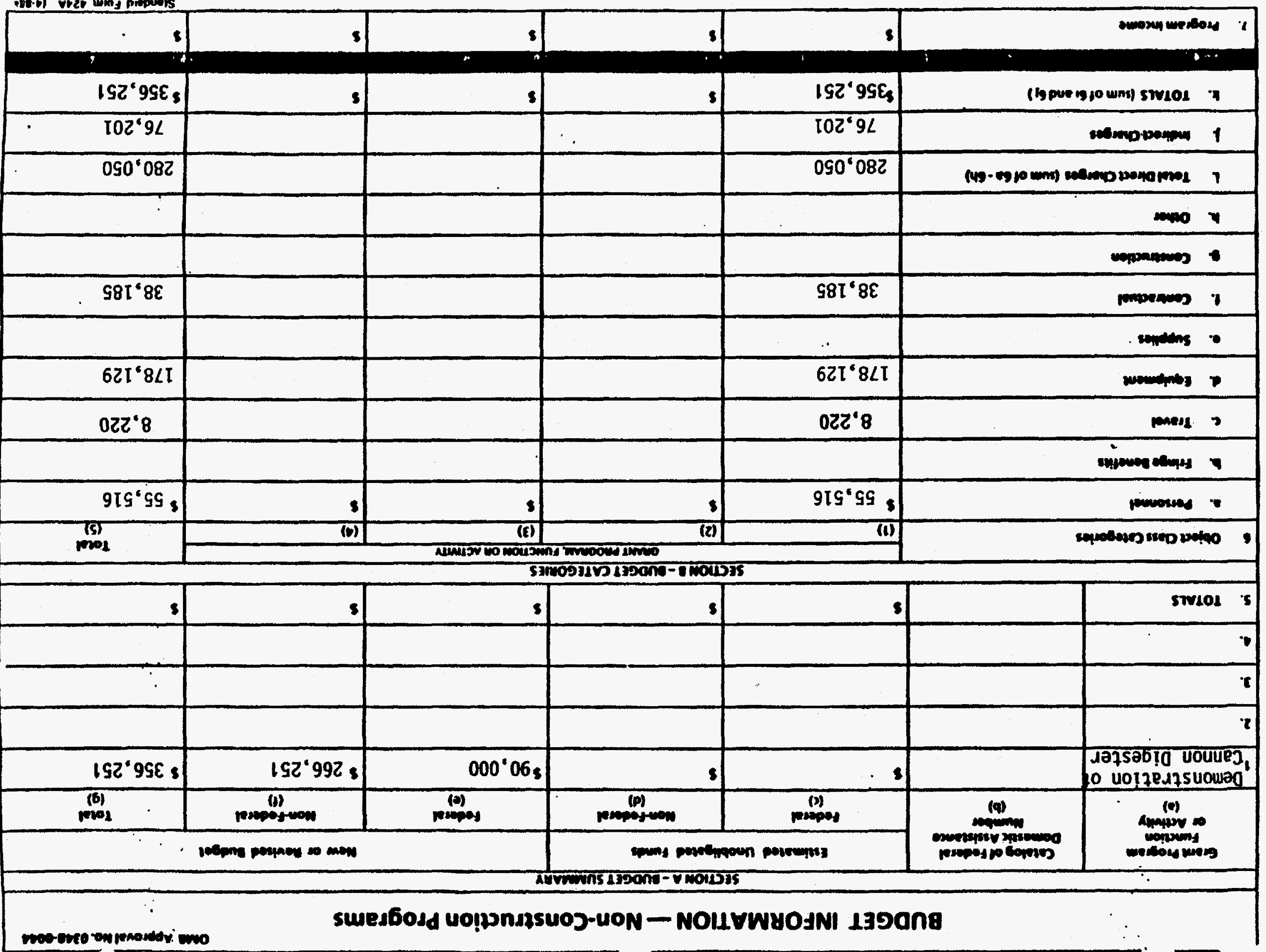




\begin{tabular}{|c|c|c|c|c|c|}
\hline \multicolumn{6}{|c|}{ SECTIONC-MON-FEDERAL MESOUACES } \\
\hline \multicolumn{2}{|l|}{ Lescemenerem } & 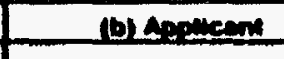 & (e) 204 & (d) Oen sonsece & Gerrorals \\
\hline \multicolumn{2}{|l|}{ - Demonstration of Cannon Digester } & 116,249 & 30,000 & 120,002 & 266,251 \\
\hline \multicolumn{6}{|l|}{ s. } \\
\hline \multicolumn{6}{|l|}{10.} \\
\hline \multicolumn{2}{|l|}{11.} & & & & . \\
\hline \multicolumn{2}{|l|}{ 12. Totacs (sum of lmese and 11) } & 1116,249 & s 30,000 & 120,002 & s. 266,251 \\
\hline \multicolumn{6}{|c|}{ SECTON D - FONECASTEO CASH MEEDS } \\
\hline \multirow{2}{*}{ 13. Fenterel } & 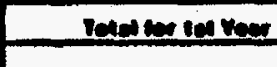 & res ovener & 2asenenen & 2ulounder & an oventer \\
\hline & s 90,000 & 54,000 & 27,000 & s 4,500 & s 4,500 \\
\hline 14. nenfoderal & 266,251 & 159,750 & 79,876 & 13,313 & 13,312 \\
\hline 15. rotal (swom of hnes 13 and 19 ) & 356,251 & $\$ 213,750$ & 106,876 & 17,813 & s 17,812 \\
\hline \multicolumn{6}{|c|}{ SECION E- WUDCET ESTMMATES OF FEDERAL FUNDS NEEDED FOR MALANCE OF THE PAOIECT } \\
\hline \multicolumn{2}{|c|}{ (a) Cann Progen } & \multicolumn{4}{|c|}{ 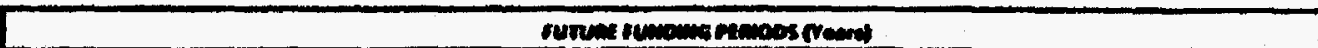 } \\
\hline 16. Demonstration of Cannon Digester & & 90,000 & dencent & Cond & (d) founth \\
\hline \multicolumn{2}{|l|}{11.} & & & & \\
\hline \multicolumn{2}{|l|}{10.} & & & & \\
\hline \multicolumn{2}{|l|}{19.} & & & & \\
\hline \multicolumn{2}{|l|}{ 20. Totals (fum of lunes $16-19$ ) } & 90,000 & $s$ & $s$ & s \\
\hline \multicolumn{6}{|c|}{ 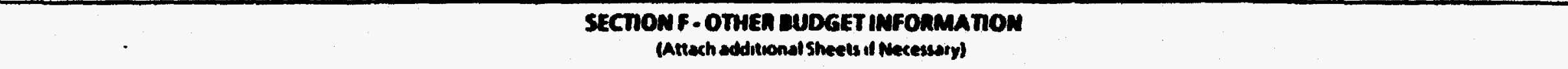 } \\
\hline \multicolumn{2}{|l|}{ 21. Dineca Charem: } & \multicolumn{3}{|c|}{ 22. Mrect Chares: 76,201 Provisional } & \\
\hline \multicolumn{6}{|l|}{ 23. Remusts. } \\
\hline
\end{tabular}




\begin{tabular}{|c|r|r|r|r|r|r|r|}
\hline \multicolumn{7}{|c|}{ TABLE 1: DISTRIBUTION OF EXPENSES AMONG PARTICIPANTS } \\
\hline Cost Category & Amount & Budget & U.S. DOE & SoCalGas & Alta Dena & SCAQMD & Cannon \\
\hline & & & & & & & \\
\hline LABOR: & & & & & & \\
\hline Engineering & $\$ 23,046$ & & $\$ 5,422$ & $\$ 3,614$ & $\$ 3,614$ & $\$ 1,627$ & $\$ 8,769$ \\
\hline Shop Labor & 25,809 & & 6,072 & 4,048 & 4,048 & 1,822 & 9,820 \\
\hline Sub-total & $\$ 48,855$ & $\$ 55,516$ & $\$ 11,494$ & $\$ 7,662$ & $\$ 7,662$ & $\$ 3,449$ & $\$ 18,589$ \\
\hline Fringe Benefits-26\% & 12,702 & & 2,988 & 1,992 & 1,992 & 896 & 4,833 \\
\hline Sub-total Labor & $\$ 61,557$ & $\$ 55,516$ & $\$ 14,482$ & $\$ 9,654$ & $\$ 9,654$ & $\$ 4,345$ & $\$ 23,422$ \\
\hline Equipment & & & & & & & \\
\hline Travel & 193,409 & 178,129 & 45,501 & 30,335 & 30,335 & 13,650 & 73,590 \\
\hline Contractual & 1,500 & 8,220 & 353 & 235 & 235 & 106 & 571 \\
\hline Total before G. \& A. & $\$ 29,460$ & 38,185 & 8,577 & 5,718 & 5,718 & 2,573 & 13,873 \\
\hline G and A & 89,635 & $\$ 280,050$ & $\$ 68,913$ & $\$ 45,942$ & $\$ 45,942$ & $\$ 20,674$ & $\$ 111,456$ \\
\hline Grand Total & & 76,201 & 21,087 & 14,058 & 14,058 & 6,326 & 34,105 \\
\hline & & & & & & \\
\hline
\end{tabular}




\section{APPENDIX D}

NEW TEST PROTOCOL

FOR ALTA DENA DEMONSTRATION 


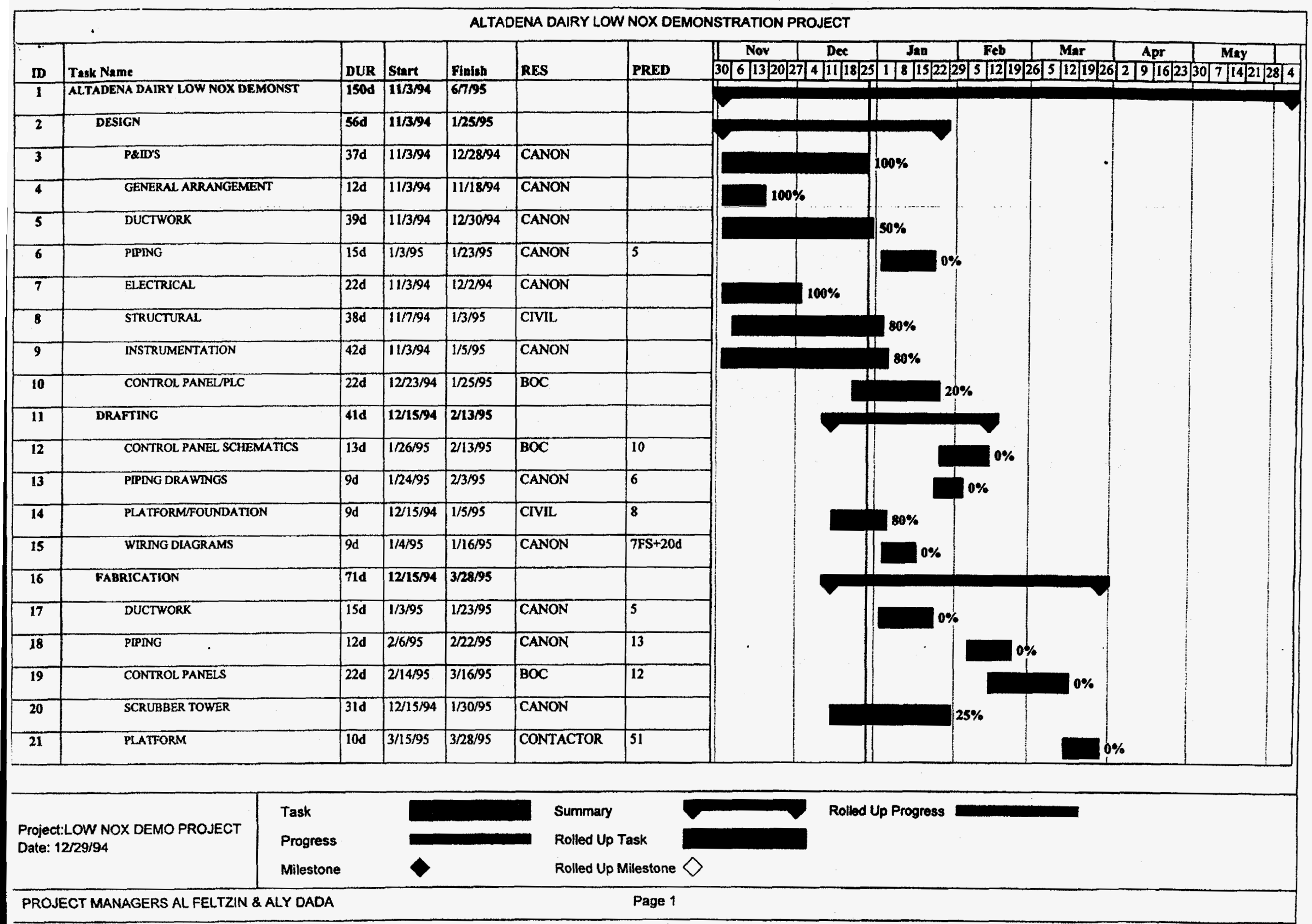




\section{APPENDIX E}

\section{NEW TIME SCHEDULE}

FOR ALTA DENA DEMONSTRATION 


\section{TEST PROTOCOL \\ ALTA DENA DEMONSTRATION \\ OF THE \\ CANNON TECHNOLOGY LTO SYSTEM}

\subsection{START-UP TESTS}

The system will be inspected for adherence to the installation drawings, the specifications and the P \& I.D. The LTO system will then be started-up exactly as specified by the Cannon Technology "LTO Start-UP Manual". This test will verify that all components have been installed properly, are operating properly and adhere to design specifications. The components tested will include the two economizers. fan, pumps, spray systems in the packed tower, ozone generator, ducting and piping, control systems and instrumentation. Start-up will include debugging of the system to adjust/repair equipment as necessary to achieve proper operation of all components and the overall system.

\subsection{BASELINE TESTING}

A thirty day shake-down test will be conducted in three parts as explained below. During this entire period the following data will be recorded using a digital computerbased control and data acquisition system:

a. Temperatures of the exhaust gas stream at least five (5) locations between the boiler outlet and the LTO stack.

b. Exhaust gas flow rate at inlet to the fan.

c. NOx and oxygen $(\mathrm{O} 2)$ concentrations at the exit of the condensing economizer and NOx at the entrance to the packed tower.

d. Ozone concentration (in per cent by weight) at the exit of the ozone generator.

e. $\mathrm{NOx}, \mathrm{O}_{2}, \mathrm{CO}$ at the exit of the condensing economizer

$\mathrm{NOx}$, and $\mathrm{CO}$ at the entrance of the packed tower

$\mathrm{CO}, \mathrm{CO}_{2}, \mathrm{O}_{2}, \mathrm{O}_{3}, \mathrm{NO}$ and $\mathrm{NO}_{2}$ at the exit of the ozone destructor unit.

$\mathrm{O}_{3}, \mathrm{NO}$ and $\mathrm{NO}_{2}$ at exit of the demister

f. Water flow rate to the packed tower spray nozzles.

g. Water pressure at the packed tower spray nozzles.

h. $\mathrm{pH}$ of solution in the packed tower holding tank.

j. Temperatures of the water entering and exiting the high temperature economizer.

k. Temperatures of the exhaust gas entering and exiting the high temperature economizer.

1. Temperatures of the water entering and exiting the condensing economizer.

$\mathrm{m}$. Temperatures of the exhaust gas entering and exiting the condensing economizer.

n. Exhaust gas pressures at three (3) locations along the ducting between the fan inlet and the demister outlet. 
o. Electrical energy (Kw-hr) used by the ozonator, the fan and the pumps.

p. Elapsed time for system operations from an elapsed time meter.

q. Date and time tags on acquired data.

r. Total water used for ozone generator cooling.

s. Total system make-up water supplied.

t. Total water release from packed tower.

u. Boiler feed water flow rate.

\subsection{Uncontrolled Boiler Performance Test}

For one week of testing the boiler will be operated with the FGR system deactivated by switching the fan off and closing the FGR duct dampers. The LTO system will be operated with the ozone generator deactivated, with the packed tower dry and with no packing installed, and with both recuperators cooling water flows by-passed. The objective of this testing is to provide an accurate basis with which to compare and evaluate the Cannon LTO system when it is fully operational.

\subsection{Economizer Performance Testing}

For one week the system will be operated without activating the ozonator and with the packed tower dry, but with the water flows restored to the economizers. The objective of this test is to determine the heat exchanger performance and boiler efficiency improvement.

\subsection{NOx Emissions Compliance Testing*}

For the last two weeks of the baseline testing, the LTO system will be fully activated and the $\mathrm{O}_{3} / \mathrm{NO}$ molar ratio adjusted to achieve NOx emission levels of $40 \mathrm{ppmv}$ (corrected to 3\% oxygen). The flue gas recycle fan must be turned off and the dampers closed in order to bring the NOx levels, at input to the LTO system, to the uncontrolled values. Prior to installation of the FGR system the NOx emission levels were near to 70 ppmv and it is assumed that approximately the same values will be seen during these tests. The objective of this test is to evaluate system performance at conditions that comply with SCAQMD District Rule 1146. Test data will be evaluated and used to perform an economic analysis for determining the system operating costs for maintaining compliance with District rules.

* Before proceeding to compliance testing, the tower will be operated as a spray column and the removal of NOx will be studied at different NOx levels and different O3/NOx ratios. 


\subsection{LTO SYSTEM OPTIMIZATION TESTS}

Following the completion of the NOx emissions compliance tests, the FGR dampers will be adjusted to maintain a NOx emissions level of $40 \mathrm{ppmv}$ (corrected to $3 \% \mathrm{O}_{2}$ ) at inlet to the LTO system and the LTO system will be adjusted to maintain a NOx emission level of less than $2.0 \mathrm{ppmv}$ (corrected to $3 \% \mathrm{O}_{2}$ ). The expected duration of these tests is three (3) weeks. The optimization is to proceed by adjusting liquid flow rates to the packed column and the selection of the best $\mathrm{HNO}_{3}$ neutralizing methodology.

\subsection{Packed Tower Spray Tests}

The optimum flow rates will be determined by varying the flow to the packed tower nozzles using a bypass valve. The liquid flow will be reduced in steps to determine its effect on the removal of NOx.

\subsection{Neutralization Methodology Tests}

Tests will be carried out in acidic and alkaline media. For the alkaline medium, an alkali (either $\mathrm{NaOH}$ or $\mathrm{Na}_{2} \mathrm{CO}_{3}$ ) will be added to the scrubber water and the $\mathrm{pH}$ will be maintained above 7.0. For the acidic medium no caustic will be added and the $\mathrm{HNO}_{3}$ formed in situ will lower the $\mathrm{pH}$ below 7.0. NOx removal efficiencies will be measured for each of the cases investigated.

\subsection{LONG TERM TESTING AND MONITORING}

\subsection{Remote Monitoring Tests}

For a period of nine (9) months the system will be operated by Alta Dena Dairy personnel and monitored in Pittsburgh, PA by Cannon Technology. Data will be transferred daily to Pittsburgh using non-dedicated telephone lines. The remote monitoring will establish the operating record for demonstrating the long term performance of the Cannon LTO system. System upsets and gradual drifts toward non-compliant emissions can be diagnosed in Pittsburgh and appropriate changes in system operation can be recommended and the resultant effects observed there through telephone hook-up.

\subsection{Final Demonstration of System Performance.}

A thirty (30) day test period will be carried out after Cannon's personnel make the final adjustments to the system as dictated by the long term data and the operator's experience. The LTO system will be under the control of Cannon personnel but the data 
gathering will be done by a third party testing organization and will be witnessed by District personnel to verify final system performance. Instrumentation specified by the outside testing organization, other than that installed originally by Cannon, will be supplied by that organization or by the District.

\subsection{POST TEST DISPOSITION OF LTO SYSTEM}

After completion of the final demonstration test, the Cannon LTO system will be turned over to the Alta Dena Dairy, at their discretion, for their continuing use for NOx emissions reduction. 